\title{
From Cold War Sanctions to Weaponized Interdependence
} An Annotated Bibliography on Competition and Control over Emerging Technologies

\section{CSET Data Brief}

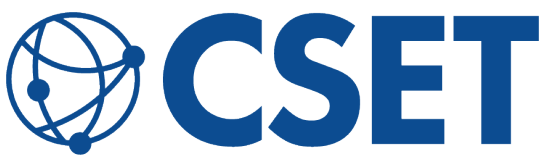

CENTER for SECURITY and EMERGING TECHNOLOGY

\section{AUTHORS}

Adam Kline

Tim Hwang 


\section{Table of Contents}

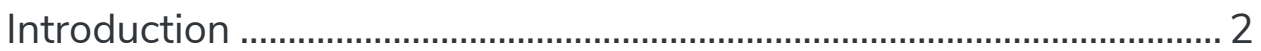

Observations and Key Takeaways .......................................................... 3

Theory of Strategic Economic Competition and Statecraft ................ 5

Export Controls and Technology Transfer during the Cold War

Strategic Economic Competition and Export Controls after the Cold War.........................................................................................23

Economic and Technological Competition: U.S.-Japan .....................29

Strategic, Economic, and Technological Competition:





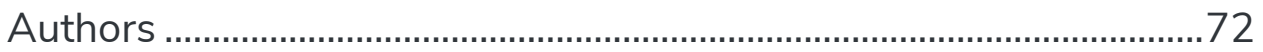

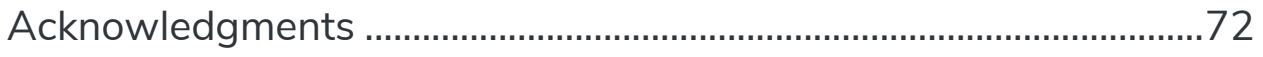

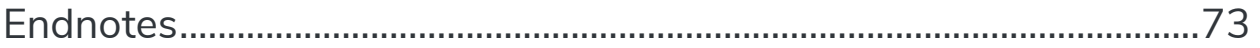




\section{Introduction}

CSET is providing this annotated bibliography as a resource for researchers interested in studying the history and future of international competition and control over emerging technologies. We hope that this review will prove useful for scholars interested in the history of Cold War economic and technological policies, technological competitiveness, economic statecraft, and the escalating technological rivalry between Beijing and Washington. It covers decades of scholarship on technology and strategic economic competition, drawing from a wide variety of sources, from journal articles to declassified CIA documents, and a range of perspectives, from academics to policymakers.

The bibliography includes five main sections. Each section features an introduction synthesizing its contents and then lists and briefly summarizes individual sources in chronological order. First is a section surveying the hefty theoretical literature on economic interdependence, conflict, and economic statecraft, including perennial debates over the "commercial peace" theory and the efficacy of sanctions. The next two sections review strategic economic competition, export controls, and technology transfer policies during the Cold War and the post-Cold War era. The fourth section concentrates on U.S. fears of domestic economic decline and technological dependence on Japan in the 1980s and early 1990s. The final section focuses on scholarly discussions of China's rise, U.S. export controls and technology transfer policies toward Beijing, and a potential U.S.-China decoupling. 


\section{Observations and Key Takeaways}

This review suggests several important lessons for scholars and policymakers grappling with the thorny challenges of strategic economic and technological competition.

First, economics and technology are crucial components of national security and key factors influencing geopolitical outcomes. A strong economy can achieve technological breakthroughs that, in turn, help fuel economic growth and development. States can exploit economic and technological power to wield international power and influence, including by drawing upon their technological capabilities to develop cutting-edge weapon systems that enhance national military might. In the Cold War, the economic and technological advantages enjoyed by the United States and its allies forced the Soviet Union to play catch-up and helped NATO offset Soviet military advantages. The transatlantic alliance, along with Japan, established the Coordinating Committee for Multilateral Export Controls (COCOM) early in the Cold War to harmonize technology transfer policy against Communist states. In the 1980s and early 1990s, Japan's impressive economic growth and technological development led many U.S. observers to fear that Tokyo would convert its burgeoning commercial strength into hard power and match or overtake the United States. Yet in the current U.S. confrontation with China, Washington and Beijing are far more evenly matched, presenting an even greater challenge.

Second, the literature also demonstrates the value and limitations of export controls and technology transfer regulations. Export controls may lead to security gains at the cost of economic and diplomatic losses. For instance, restricting exports of Technology $X$ may deny its military benefits to Country Y; however, the manufacturers of Technology $X$ could suffer lost revenue and reduced competitiveness, and foreign allies may chafe if the regulations impact their own industries. ITAR regulations on the U.S. space industry are an important example of the many unintended consequences of export controls, especially their potentially adverse long-term economic and strategic consequences. There are no hard-and-fast rules governing these 
calculations, and officials must carefully evaluate trade-offs before implementing wide-ranging technology transfer policies.

Third, many experts agree that when enacting technology controls, policymakers should prioritize multilateralism and coordination with allies over unilateral and abrupt moves that alienate foreign partners. Not only do unilateral export controls run the risk of diplomatic damage, but they are less effective than multilateral efforts. Robust diplomatic, intelligence, and law enforcement cooperation is key to shoring up multilateral technology control regimes. Otherwise, adversaries can capitalize upon allied disunity to obtain protected technologies. The determining factor is the availability of the technology in question, since unilateral export controls are futile if a given technology is easily obtainable through other partner states.

Fourth, export controls are a delaying measure, not a permanent solution for the problem of technology transfer to adversaries. The technological laggard is on the offensive, maintaining the initiative and enjoying plentiful means of acquisition-including cyberespionage, front companies, and insider agents. At the same time, the technological leader is playing defense, forced to continually protect intellectual property, human capital, physical goods, and digital networks. Indeed, even without the benefits of industrial cyberespionage, the Soviet Union still used its intelligence agencies and other state organs to great effect in its decades-long campaigns to acquire advanced foreign technology. Try as they might, it is impossible for states to permanently safeguard technologies against well-resourced and aggressive state acquisition efforts.

Finally, when formulating export controls and technology transfer policies, officials must be prepared to swiftly update them as the technology evolves. As new technologies emerge and diffuse, and as standards adapt, export control policies must change accordingly. Maintaining obsolete restrictions on the books is ineffective and counterproductive. In some cases, if a given technology becomes sufficiently widespread, export controls will serve as little more than a bureaucratic hindrance for companies. Thus, policymakers should develop efficient mechanisms for 
modernizing regulations as the state of the field changes, lest export controls and technology transfer rules be rendered obsolete.

\section{Theory of Strategic Economic Competition and Statecraft}

The literature on economics, interdependence, and conflict is truly vast and spans centuries. This section covers a number of prominent topics in the domain, including the relationship between interdependence and conflict, the concept of "economic security," and the disputed efficacy of economic sanctions. This section also covers the theory and practice of embargoes and economic warfare. A perennial academic debate is whether interdependence fosters peace (the "commercial peace" theory) or creates incentives for war. Experts have also considered whether the globalization of production, international financial flows, and an information-based global economy have helped to promote peace. Just as scholars have historically shown how trade can enable a dominant power to cultivate political influence in a less powerful state, more recent work has explored "weaponized interdependence"- the leveraging of economic ties to shape and influence adversary behavior-in international economics and technology. This section also includes a number of case studies exploring economic coercion, from the United States and Hawaii to India and Nepal.

Table 1: Selected Publications on Theory of Strategic Economic Competition and Statecraft

\begin{tabular}{|l|l|}
\hline Publication & Summary \\
\hline Knorr 1975 & $\begin{array}{l}\text { In the wake of the OPEC oil crisis, Knorr disagrees with } \\
\text { the notion "that economic power is becoming } \\
\text { increasingly important in shaping international relations, } \\
\text { or ... a substitute for military power." He notes that } \\
\text { military, public opinion, diplomatic, and trade factors } \\
\text { influence the outcome of attempted economic coercion. }\end{array}$ \\
\hline Navari 1989 & $\begin{array}{l}\text { Navari examines the writings of Norman Angell, an early } \\
\text { international relations theorist who argued prior to World }\end{array}$ \\
\hline
\end{tabular}




\begin{tabular}{|c|c|}
\hline & $\begin{array}{l}\text { War I that international economic interdependence would } \\
\text { check state incentives for war. Navari outlines Angell's } \\
\text { theory of modernity and interdependence, critiquing its } \\
\text { "excessive generality" and insufficient attention to state } \\
\text { power and nationalism. However, she highlights Angell's } \\
\text { recognition of how growing interdependence would } \\
\text { affect international politics. }\end{array}$ \\
\hline Førland 1991 & $\begin{array}{l}\text { Førland emphasizes that the Coordinating Committee for } \\
\text { Multilateral Export Controls cannot be seen in terms of } \\
\text { economic sanctions, but rather as a tool of economic } \\
\text { warfare. Sanctions are a coercive tool, while COCOM } \\
\text { aimed to impede Soviet military capabilities. He offers a } \\
\text { theoretical discussion on the definition of economic } \\
\text { warfare and sides with President Dwight D. Eisenhower } \\
\text { in rejecting the notion of inherent "strategic goods." }\end{array}$ \\
\hline Førland 1993 & $\begin{array}{l}\text { Provides a pessimistic perspective on economic warfare, } \\
\text { finding it "impotent when waged against a confident and } \\
\text { ruthless power elite with a firm grip on the army." } \\
\text { Førland contends that "The top strategic item is ... the } \\
\text { one that is relatively most expensive for the importing } \\
\text { country to produce domestically and therefore gives the } \\
\text { largest gains from trade." }\end{array}$ \\
\hline Cable 1995 & $\begin{array}{l}\text { Cable describes the emerging fusion of economic and } \\
\text { security issues amidst globalization and international } \\
\text { interdependence. He objects to the concepts of economic } \\
\text { security and geo-economics, calling the former too broad } \\
\text { and the latter too narrowly focused on unilateral action } \\
\text { over multilateralism. }\end{array}$ \\
\hline Barbieri 1996 & $\begin{array}{l}\text { Contrary to conventional wisdom, Barbieri finds that } \\
\text { "[E]xtensive economic interdependence increases the } \\
\text { likelihood that dyads engage in militarized dispute" but } \\
\text { does not significantly affect "the incidence of war." }\end{array}$ \\
\hline
\end{tabular}




\begin{tabular}{|c|c|}
\hline $\begin{array}{l}\text { Morgan and } \\
\text { Schwebach } \\
1997\end{array}$ & $\begin{array}{l}\text { Using a spatial model, the authors present a pessimistic } \\
\text { view of sanctions, writing that "In most cases, a state } \\
\text { imposing sanctions ... can expect an outcome that is just } \\
\text { about the same as would be obtained without sanctions." }\end{array}$ \\
\hline McMillan 1997 & $\begin{array}{l}\text { McMillan conducts a literature review, concluding that } \\
\text { studies generally affirm the pacifying effect of } \\
\text { interdependence. She suggests potential avenues for } \\
\text { further scholarly work, including the question of how to } \\
\text { quantify interdependence. }\end{array}$ \\
\hline Pape 1997 & $\begin{array}{l}\text { Pape insists that economic sanctions are ineffective due } \\
\text { to nationalism, state countermeasures, and elites } \\
\text { redistributing the economic burden onto other groups. } \\
\text { However, sanctions may work better in marginal disputes } \\
\text { and on dependent or economically unequal states. }\end{array}$ \\
\hline $\begin{array}{l}\text { Mastanduno } \\
1998\end{array}$ & $\begin{array}{l}\text { Mastanduno suggests that international multipolarity and } \\
\text { unipolarity spur the alignment of economic and security } \\
\text { issues, while bipolarity discourages it. Two other factors } \\
\text { influencing alignment are the severity of threats and state } \\
\text { competitiveness. }\end{array}$ \\
\hline $\begin{array}{l}\text { Barbieri and } \\
\text { Levy } 1999\end{array}$ & $\begin{array}{l}\text { Barbieri and Levy write that both liberal and realist } \\
\text { theories expect trade between two countries to be } \\
\text { sharply curtailed or blocked entirely during conflict. } \\
\text { However, the authors find otherwise and urge a } \\
\text { reconsideration of the dominant theories. }\end{array}$ \\
\hline $\begin{array}{l}\text { Liberman } \\
\text { 1999/2000 }\end{array}$ & $\begin{array}{l}\text { Examining Japanese and German expansion, Liberman } \\
\text { finds that "Expecting protracted attrition warfare with } \\
\text { severed trade links gives trade-dependent states } \\
\text { powerful security incentives to seize resource-rich } \\
\text { territory.... [l]nterdependence... heightens incentives to } \\
\text { shore up economic vulnerabilities through expansion." }\end{array}$ \\
\hline
\end{tabular}




\begin{tabular}{|c|c|}
\hline & $\begin{array}{l}\text { The combination of "defense dominance and economic } \\
\text { interdependence" can thus incentivize conquest. }\end{array}$ \\
\hline $\begin{array}{l}\text { Abdelal and } \\
\text { Kirshner } \\
1999 / 2000\end{array}$ & $\begin{array}{l}\text { Citing Albert Hirschman, an early scholar of asymmetric } \\
\text { trade, this study shows how economic dependence can } \\
\text { create domestic constituencies with vested interests that } \\
\text { benefit the dominant power. Abdelal and Kirshner use } \\
\text { case studies of the United States and Hawaii, Austria and } \\
\text { Czechoslovakia, and Ukraine and Russia to illustrate the } \\
\text { theory in practice. }\end{array}$ \\
\hline $\begin{array}{l}\text { Blanchard and } \\
\text { Ripsman } \\
\text { 1999/2000 }\end{array}$ & $\begin{array}{l}\text { Blanchard and Ripsman conduct three case studies: } 1933 \\
\text { British sanctions on the Soviet Union, } 1979 \text { Arab League } \\
\text { sanctions on Canada, and } 1989-1990 \text { Indian sanctions } \\
\text { on Nepal. They conclude that "[E]conomic coercion } \\
\text { worked primarily because domestic and international } \\
\text { political conditions existed that magnified the political } \\
\text { costs of noncompliance for the target state." They stress } \\
\text { the importance of political costs, not economic costs, but } \\
\text { note that policymakers can mitigate political costs } \\
\text { "resulting from economic distress." }\end{array}$ \\
\hline $\begin{array}{l}\text { Mastanduno } \\
1999 / 2000\end{array}$ & $\begin{array}{l}\text { Mastanduno reviews scholarly discussions on the effects } \\
\text { and effectiveness of economic sanctions, policy } \\
\text { integration, methodological issues in research, questions } \\
\text { of interdependence and war, and similar topics. }\end{array}$ \\
\hline Brooks 1999 & $\begin{array}{l}\text { Brooks asserts that increased economic globalization has } \\
\text { reduced the incentives for conquest among highly } \\
\text { developed countries. He cites several factors driving this } \\
\text { trend, including "the increased geographic dispersion of } \\
\text { production," "the greatly enhanced significance of } \\
\text { interfirm alliances," and "the general shift toward } \\
\text { "knowledge-based' economies in the most advanced } \\
\text { countries." His article also includes an in-depth literature } \\
\text { review on economics and conquest. }\end{array}$ \\
\hline
\end{tabular}




\begin{tabular}{|c|c|}
\hline $\begin{array}{l}\text { Bolks and Al- } \\
\text { Sowayel } 2000\end{array}$ & $\begin{array}{l}\text { Bolks and Al-Sowayel determine that the target state's } \\
\text { "political structure and regime stability" influence the } \\
\text { duration of sanctions, also finding that sanctions involve } \\
\text { high costs and lengthy timespans. }\end{array}$ \\
\hline Brooks 2002 & $\begin{array}{l}\text { Using the case studies of South Africa, Iraq, Haiti, and } \\
\text { Yugoslavia, Brooks concludes that sanctions that impact } \\
\text { ordinary citizens or certain constituencies are "effective } \\
\text { against democratic states." Meanwhile, targeted } \\
\text { sanctions against regime insiders are more effective } \\
\text { when confronting authoritarian states. }\end{array}$ \\
\hline $\begin{array}{l}\text { McGillivray and } \\
\text { Stam } 2004\end{array}$ & $\begin{array}{l}\text { The authors find that "[L]eadership change strongly } \\
\text { affects the duration of sanctions only in the case of } \\
\text { nondemocratic systems." }\end{array}$ \\
\hline Allen 2005 & $\begin{array}{l}\text { Allen examines the domestic factors behind economic } \\
\text { sanction outcomes, such as domestic politics and regime } \\
\text { type. For instance, she concludes that "The presence of a } \\
\text { democratic target shortens the duration of sanctions." }\end{array}$ \\
\hline $\begin{array}{l}\text { Hufbauer, } \\
\text { Schott, Elliott, } \\
\text { and Oegg } 2007\end{array}$ & $\begin{array}{l}\text { This major study of sanctions relies on } 174 \text { sanctions } \\
\text { cases ranging from World War I to the year } 2000 \text {. The } \\
\text { authors note the symbolic role of sanctions, the } \\
\text { significance of domestic politics, the reasons why } \\
\text { sanctions fail, and more. They state that sanctions were } \\
\text { "at least partially successful in } 34 \text { percent of the cases," } \\
\text { but sanctions conducted with narrower aims were more } \\
\text { successful than those implemented for regime change or } \\
\text { military purposes. }\end{array}$ \\
\hline $\begin{array}{l}\text { Hegre, Oneal, } \\
\text { and Russett } \\
2010\end{array}$ & $\begin{array}{l}\text { This is another contribution in the extensive academic } \\
\text { literature on whether economic interdependence through } \\
\text { trade leads to peace. Hegre, Oneal, and Russett use a } \\
\text { gravity model of trade to answer this question in the } \\
\text { affirmative. They also write that by around } 2004-2005 \text {, }\end{array}$ \\
\hline
\end{tabular}




\begin{tabular}{|l|l|}
\hline & $\begin{array}{l}\text { even skeptics of the commercial peace argument } \\
\text { acknowledged that there was a rough consensus } \\
\text { favoring the hypothesis. }\end{array}$ \\
\hline Ronis 2011 & $\begin{array}{l}\text { This edited volume contains chapters on energy security, } \\
\text { education, and innovation as part of national security. }\end{array}$ \\
\hline Lupu 2012 & $\begin{array}{l}\text { Gartzke and Lupu defend the commercial peace theory, } \\
\text { which many critics attempt to invalidate by citing the } \\
\text { case of World War I. The authors show that the war } \\
\text { started among less interdependent states closely allied } \\
\text { with more interdependent great powers. They find that, } \\
\text { in fact, "[E]conomic linkages served an important role in } \\
\text { averting escalation to warfare in the series of crises that } \\
\text { led up to the Great War." }\end{array}$ \\
\hline Whang and & $\begin{array}{l}\text { The authors analyze sanctions from a signaling } \\
\text { perspective, showing that sanctions do not impose } \\
\text { sufficient costs on the imposing state to demonstrate its } \\
\text { seriousness and determination to the target state. }\end{array}$ \\
\hline Blackwill and \\
Harris 2016
\end{tabular}




\begin{tabular}{|c|c|}
\hline $\begin{array}{l}\text { Gowa and } \\
\text { Hicks } 2017\end{array}$ & $\begin{array}{l}\text { The authors analyze data on trade during World War I, } \\
\text { determining that "Rather than resulting in a wholesale } \\
\text { breakdown of trade, the war rerouted it along the fault } \\
\text { lines it created." These changes were facilitated by the } \\
\text { substitutability of goods. }\end{array}$ \\
\hline $\begin{array}{l}\text { McCormack } \\
\text { and Pascoe } \\
2017\end{array}$ & $\begin{array}{l}\text { McCormack and Pascoe theorize that sanctions function } \\
\text { as buffers against war "by destroying targeted states' } \\
\text { military power... [and] prevent[ing] adverse shifts in the } \\
\text { distribution of power that could otherwise lead to armed } \\
\text { conflict." Their examples include U.S. sanctions on Iran } \\
\text { since } 1979 \text { and Japan before World War II. They suggest } \\
\text { that "Scholars and policy makers should ask... what } \\
\text { target state behavior would have looked like had } \\
\text { sanctions not been imposed." }\end{array}$ \\
\hline $\begin{array}{l}\text { Roberts, Choer } \\
\text { Moraes, and } \\
\text { Ferguson } 2018\end{array}$ & $\begin{array}{l}\text { The authors suggest that "the old International Economic } \\
\text { World Order" featured greater distinctions between } \\
\text { economics and security, while under the "emerging } \\
\text { Geoeconomic World Order," the two are more closely } \\
\text { aligned. The transition point between the two was } \\
\text { around 2017-2018. They describe "economic } \\
\text { convergence that has changed the geopolitical balance of } \\
\text { power" and the shifting focus from absolute to relative } \\
\text { gains. }\end{array}$ \\
\hline $\begin{array}{l}\text { Drezner, Farrell, } \\
\text { and Newman } \\
2021\end{array}$ & $\begin{array}{l}\text { An edited volume of essays building upon Henry Farrell } \\
\text { and Abraham L. Newman's concept of "weaponized } \\
\text { interdependence." The contributions cover topics ranging } \\
\text { from international finance and technological } \\
\text { interdependence to Russia's Gazprom and China's Belt } \\
\text { and Road Initiative. }\end{array}$ \\
\hline
\end{tabular}




\section{Export Controls and Technology Transfer during the Cold War}

Amidst the high drama of the Cold War, a battle raged over the Soviet Union's attempts to gain access to U.S. high technologywhich, Washington feared, could negate NATO's qualitative military edge over Warsaw Pact forces. Working through COCOM, the United States and its allies attempted to harmonize their export restrictions and deny their adversaries access to sensitive technologies as Moscow and its allies mounted a sustained espionage offensive. Over the decades, significant controversies periodically erupted within and between governments over export control breaches and U.S. efforts to block the transfer of certain technologies to the Soviet Union. From the Kama River truck plant to Siberian pipeline sanctions and the Toshiba-Kongsberg case, these polemics spilled over into congressional debate, media coverage, and academic attention. A key theme in this sectionwhich scholars and policymakers alike debated-is the fundamental question of which items should be protected and how best the government should do so. Another recurring strand is the need for multilateral cooperation, including through COCOM, in order to effectively control technology transfer. This section also includes sources on Soviet military-industrial espionage, including intelligence documents, academic studies, and major works based on primary materials.

Table 2: Selected Publications on Export Controls and Technology Transfer during the Cold War

\begin{tabular}{|l|l|}
\hline Publication & Summary \\
\hline $\begin{array}{l}\text { CIA Directorate } \\
\text { of Intelligence } \\
1970\end{array}$ & $\begin{array}{l}\text { This intelligence document discusses COCOM technology } \\
\text { exports to the Soviet bloc and resulting intra-alliance } \\
\text { disagreements. It includes statistics on "exceptions } \\
\text { requests" and their projected economic value, as well as } \\
\text { the overall volume of trade. }\end{array}$ \\
\hline
\end{tabular}




\begin{tabular}{|c|c|}
\hline $\begin{array}{l}\text { Defense } \\
\text { Science Board } \\
\text { Task Force on } \\
\text { Export of U.S. } \\
\text { Technology } \\
1976\end{array}$ & $\begin{array}{l}\text { Produced by a Pentagon panel headed by J. Fred Bucy, } \\
\text { this major study of export controls and technology } \\
\text { transfer emphasized controlling revolutionary } \\
\text { technologies, not products, and reducing COCOM lists. It } \\
\text { declared that "[C]ontrol of design and manufacturing } \\
\text { know-how is absolutely vital to the maintenance of U.S. } \\
\text { technological superiority," a finding that has significantly } \\
\text { influenced the export control literature. }\end{array}$ \\
\hline $\begin{array}{l}\text { Office of } \\
\text { Technology } \\
\text { Assessment } \\
1979\end{array}$ & $\begin{array}{l}\text { This government report analyzes patterns of East-West } \\
\text { trade and technology transfer, concluding that the scale } \\
\text { of the trade is relatively small, that export controls do not } \\
\text { significantly hamper Communist states, and that U.S. and } \\
\text { European technological products are a small but } \\
\text { disproportionately valuable part of Communist imports. It } \\
\text { includes chapters assessing economic, foreign policy, and } \\
\text { military implications, as well as discussions of COCOM, } \\
\text { the Soviet Union, and China. }\end{array}$ \\
\hline Yergin 1980 & $\begin{array}{l}\text { This monograph reviews technology transfer regulations } \\
\text { in West Germany, the United Kingdom, and France. It } \\
\text { presents a positive assessment of COCOM but urges } \\
\text { policymakers to streamline and rationalize the } \\
\text { organization's processes. }\end{array}$ \\
\hline $\begin{array}{l}\text { Bucy } \\
\text { 1980/1981 }\end{array}$ & $\begin{array}{l}\text { Bucy, the head of an influential Pentagon panel on export } \\
\text { controls, reiterates his report's main points. He insists } \\
\text { that the United States must have a coherent technology } \\
\text { transfer strategy focused on revolutionary technologies } \\
\text { with military implications. Bucy observes that "The } \\
\text { argument that the Soviets will eventually acquire any } \\
\text { item or technology they want badly enough does not } \\
\text { relieve the West of the obligation to impede that effort } \\
\text { and to make Soviet acquisition of technology as costly for } \\
\text { them as possible." }\end{array}$ \\
\hline
\end{tabular}




\begin{tabular}{|c|c|}
\hline Bricker 1981 & $\begin{array}{l}\text { Bricker, a colonel in the U.S. Air Force Reserve, presents a } \\
\text { very critical assessment of the Soviet technology transfer } \\
\text { problem and provides a list of controversial export control } \\
\text { cases, including the Dresser drill bits case. He is } \\
\text { especially scathing on the U.S. Department of } \\
\text { Commerce's role. }\end{array}$ \\
\hline $\begin{array}{l}\text { Gustafson } \\
1981\end{array}$ & $\begin{array}{l}\text { Gustafson assesses the Soviet institutions devoted to } \\
\text { technology policy. He is pessimistic about the feasibility } \\
\text { and prospects of expanded export controls, but he also } \\
\text { concludes that due to its political and economic } \\
\text { dysfunctions, the Soviet Union does a poor job of } \\
\text { effectively absorbing and capitalizing upon foreign } \\
\text { technology. Gustafson notes that "[l]n the end the } \\
\text { transfer of technology depends less on the fact that } \\
\text { knowledge and skills have been divulged than on the fact } \\
\text { that the receiver knew how to make creative use of } \\
\text { them." }\end{array}$ \\
\hline $\begin{array}{l}\text { Director of } \\
\text { Central } \\
\text { Intelligence } \\
1981\end{array}$ & $\begin{array}{l}\text { This Special National Intelligence Estimate assesses } \\
\text { Soviet military use of foreign technologies and the } \\
\text { potential effects of U.S. technology transfer regulations. } \\
\text { Its conclusions are somewhat pessimistic, emphasizing } \\
\text { the limitations of sanctions and unilateral actions. }\end{array}$ \\
\hline $\begin{array}{l}\text { Central } \\
\text { Intelligence } \\
\text { Agency } 1982\end{array}$ & $\begin{array}{l}\text { This declassified document from the } \mathrm{CIA} \text { attributes the } \\
\text { loss of U.S. technology with military applications to open } \\
\text { source acquisitions, trade transfer, and Soviet } \\
\text { intelligence. It assesses that up to } 75 \text { percent of "militarily } \\
\text { significant Western technology being acquired by the } \\
\text { Soviet Bloc" is obtained through intelligence means. The } \\
\text { memo concludes with policy recommendations, urging a } \\
\text { strategic and whole-of-government approach. }\end{array}$ \\
\hline $\begin{array}{l}\text { Director of } \\
\text { Central }\end{array}$ & $\begin{array}{l}\text { This Special National Intelligence Estimate surveys some } \\
\text { of the divides between the United States and its COCOM }\end{array}$ \\
\hline
\end{tabular}




\begin{tabular}{|c|c|}
\hline $\begin{array}{l}\text { Intelligence } \\
1982\end{array}$ & $\begin{array}{l}\text { allies over trade with the Soviet bloc; in general, } \\
\text { European allies were more supportive of trade. The SNIE } \\
\text { also includes details on each country's trade profile with } \\
\text { the Soviet bloc. It suggests that strengthening } \\
\text { "multilateral and bilateral enforcement of export controls } \\
\text { will receive broad support from the COCOM partners." }\end{array}$ \\
\hline $\begin{array}{l}\text { U.S. Congress } \\
1982\end{array}$ & $\begin{array}{l}\text { This congressional hearing includes testimony from a } \\
\text { variety of speakers, including a Soviet émigré engineer on } \\
\text { the limits of the Soviet technology transfer strategy, a } \\
\text { convicted conspirator in an Eastern bloc industrial } \\
\text { espionage plot, and numerous scientists, policymakers, } \\
\text { and intelligence officials. }\end{array}$ \\
\hline $\begin{array}{l}\text { Frost and Stent } \\
1983\end{array}$ & $\begin{array}{l}\text { Frost and Stent analyze policy divides and differing views } \\
\text { within the transatlantic alliance regarding trade with the } \\
\text { Soviet bloc. One problem is that European allies "believe } \\
\text { that East-West commercial ties are a normal, desirable } \\
\text { aspect of international relations," while the United States } \\
\text { is significantly more hawkish on trade. Another problem } \\
\text { is unilateral U.S. sanctions, such as those imposed on the } \\
\text { Siberian pipeline following the Polish martial law } \\
\text { crackdown in } 1981 \text {. Frost and Stent conclude that } \\
\text { "[T]here is no evidence that negative linkage... has ever } \\
\text { changed Soviet policies on any issues that the Kremlin } \\
\text { perceives as vital to Soviet national security. .. } \\
\text { [E]conomic sanctions have often proved more costly to } \\
\text { the West than to the East." }\end{array}$ \\
\hline Root 1984 & $\begin{array}{l}\text { Root, the former director of the State Department's Office } \\
\text { of East-West Trade-who resigned in } 1983 \text { "to protest } \\
\text { ineffective and counterproductive U.S. methods to } \\
\text { achieve stronger controls"-makes the case that effective } \\
\text { export controls demand effective multilateral cooperation. } \\
\text { He charges that unilateralism is ineffective, } \\
\text { counterproductive, and diplomatically costly for the } \\
\text { United States. Root advocates a more restrained }\end{array}$ \\
\hline
\end{tabular}




\begin{tabular}{|c|c|}
\hline & $\begin{array}{l}\text { approach to export control regulations than some Reagan } \\
\text { administration hardliners. }\end{array}$ \\
\hline Overly 1985 & $\begin{array}{l}\text { Overly provides a historical review of export controls on } \\
\text { critical technologies, along with case studies of the } \\
1980-1981 \text { grain embargo and the VAX 11-782 } \\
\text { computer. }\end{array}$ \\
\hline $\begin{array}{l}\text { Crawford and } \\
\text { Lenway } 1985\end{array}$ & $\begin{array}{l}\text { The authors examine East-West trade and COCOM, } \\
\text { including the Siberian pipeline case, through the prism of } \\
\text { "behavioral theories of organization." They write that } \\
\text { "[C]oercive means to exact compliance from Europe with } \\
\text { a policy of trade restriction ... will jeopardize long-term } \\
\text { cooperation." }\end{array}$ \\
\hline $\begin{array}{l}\text { CIA Directorate } \\
\text { of Intelligence } \\
1985\end{array}$ & $\begin{array}{l}\text { This CIA report provides details on a Soviet truck plant } \\
\text { that benefited from foreign engineering and technological } \\
\text { assistance. As the study notes, the Kama River truck } \\
\text { plant-some of whose products supplied the Soviet } \\
\text { military-"began to be viewed in the West as a prime } \\
\text { example of Soviet acquisition of modern Western } \\
\text { manufacturing technology." }\end{array}$ \\
\hline $\begin{array}{l}\text { Central } \\
\text { Intelligence } \\
\text { Agency } 1985\end{array}$ & $\begin{array}{l}\text { This in-depth report on Soviet military-industrial } \\
\text { espionage offers insights into Moscow's technology } \\
\text { transfer strategy, with statistics, case studies on acquired } \\
\text { technologies, details on involved Soviet institutions and } \\
\text { U.S. targets, and more. }\end{array}$ \\
\hline Yasuhara 1986 & $\begin{array}{l}\text { This study of the evolution of U.S. export controls toward } \\
\text { China in the early Cold War analyzes the roles of } \\
\text { occupied Japan, bureaucratic infighting, and Europe. }\end{array}$ \\
\hline Blair 1986 & $\begin{array}{l}\text { Blair complains that "[O]ften the United States } \\
\text { government does not have current information on what is } \\
\text { available from foreign competitors and frequently will not }\end{array}$ \\
\hline
\end{tabular}




\begin{tabular}{|c|c|}
\hline & $\begin{array}{l}\text { accept the statements of domestic corporations as to } \\
\text { what the foreign competition is providing." This can put } \\
\text { U.S. firms at a competitive disadvantage and renders } \\
\text { export controls counterproductive. Blair advocates "A } \\
\text { self-policing export-control system" using affidavits. }\end{array}$ \\
\hline Lam 1986 & $\begin{array}{l}\text { Lam writes that changes to the Export Administration } \\
\text { Act of } 1979 \text { and ITAR are positive but do not fully resolve } \\
\text { the challenges that universities and academic researchers } \\
\text { face from technology transfer regulations. }\end{array}$ \\
\hline Dobson 1988 & $\begin{array}{l}\text { Dobson details President John F. Kennedy's attempts to } \\
\text { liberalize U.S. embargo policies, as well as the domestic } \\
\text { political constraints that he faced. The article chronicles } \\
\text { issues such as pipeline politics and policy reviews. }\end{array}$ \\
\hline Sawchak 1988 & $\begin{array}{l}\text { Sawchak analyzes a complex bureaucratic, legal, and } \\
\text { regulatory controversy involving the Pentagon's role in } \\
\text { export controls and its competition with the Department } \\
\text { of Commerce. He details various legislative proposals } \\
\text { aimed at mitigating some of the procedural problems } \\
\text { within the export control system. }\end{array}$ \\
\hline $\begin{array}{l}\text { Kelly } 1989 ; \\
\text { Wrubel } 1989\end{array}$ & $\begin{array}{l}\text { These two articles detail a major technology transfer } \\
\text { incident from the Cold War, when the Soviet Union } \\
\text { obtained propeller milling and computer equipment from } \\
\text { Japanese and Norwegian companies, leading to the } \\
\text { development of stealthier nuclear submarines. The so- } \\
\text { called Toshiba-Kongsberg case sparked a backlash in the } \\
\text { United States and prompted Tokyo and Oslo to revise } \\
\text { their export control policies. }\end{array}$ \\
\hline $\begin{array}{l}\text { U.S. Congress } \\
1989\end{array}$ & $\begin{array}{l}\text { This congressional hearing includes testimony from } \\
\text { officials of the U.S. Departments of Commerce, State, } \\
\text { Energy, and Defense, as well as the Defense Advanced } \\
\text { Research Projects Agency, and NASA. It focuses on }\end{array}$ \\
\hline
\end{tabular}




\begin{tabular}{|c|c|}
\hline & $\begin{array}{l}\text { "foreign access to federally funded research and } \\
\text { development activities." }\end{array}$ \\
\hline $\begin{array}{l}\text { Goodman, } \\
\text { Blumenthal, } \\
\text { and Geipel } \\
\text { 1989/1990 }\end{array}$ & $\begin{array}{l}\text { The authors warn that rapid information technology } \\
\text { innovation, globalized production, and bureaucratic } \\
\text { inefficiencies are challenging export controls and harming } \\
\text { competitiveness. They urge "A more selective policy... } \\
\text { [to] allow Western countries to capitalize economically } \\
\text { on recent changes while continuing to protect our } \\
\text { national security and technological superiority." }\end{array}$ \\
\hline Spring 1990 & $\begin{array}{l}\text { Spring argues for the continuing importance of } \\
\text { technology export controls amidst Soviet decline, } \\
\text { contending that they are necessary for continued military } \\
\text { power and economic preeminence. He recommends } \\
\text { some continuity in COCOM and limited reforms. "Given } \\
\text { the fact that the Soviet Union retains an extremely potent } \\
\text { military force," Spring writes, "Western superiority in } \\
\text { military technology is still essential." }\end{array}$ \\
\hline $\begin{array}{l}\text { Mastanduno } \\
1992\end{array}$ & $\begin{array}{l}\text { This in-depth study of COCOM traces the organization's } \\
\text { history throughout the Cold War, touching on the } \\
\text { evolution of U.S. policy, the Bucy report, the revival of } \\
\text { sanctions during the Carter and Reagan administrations, } \\
\text { and the future of COCOM in the post-Cold War world. }\end{array}$ \\
\hline Crawford 1993 & $\begin{array}{l}\text { This work considers the relationship between } \\
\text { interdependence, economic vulnerability, and security. } \\
\text { Crawford includes case studies of imports and the Soviet } \\
\text { military and economy, as well as an examination of the } \\
\text { Soviet-European energy trade. Her conclusion is that } \\
\text { "State-imposed trade restrictions ... are not always the } \\
\text { only or best way to reduce vulnerability." }\end{array}$ \\
\hline Henshaw 1993 & $\begin{array}{l}\text { Henshaw offers a detailed account of COCOM's } \\
\text { institutional procedures and history and gleans a number } \\
\text { of lessons learned from the Cold War experience, }\end{array}$ \\
\hline
\end{tabular}




\begin{tabular}{|c|c|}
\hline & $\begin{array}{l}\text { including "the dangers of the politicization of export } \\
\text { controls, the futility of unilateral controls, and the } \\
\text { importance of common goals in the imposition of export } \\
\text { controls." He then scrutinizes the Missile Technology } \\
\text { Control Regime. }\end{array}$ \\
\hline Lundberg 1994 & $\begin{array}{l}\text { This exhaustive case study of U.S. intelligence and the } \\
\text { demise of the Soviet Union, prepared by the Kennedy } \\
\text { School of Government's Case Program, contextualizes } \\
\text { the longstanding debate over assessments of the Soviet } \\
\text { economy. }\end{array}$ \\
\hline Weiss 1996 & $\begin{array}{l}\text { This is an account of Soviet technological espionage in } \\
\text { the } 1970 \text { s and the U.S. response, written by a national } \\
\text { security insider. Weiss details the Farewell Dossier- } \\
\text { revelations of Soviet industrial espionage by a defector- } \\
\text { and alleges an U.S. campaign of supply-chain sabotage. }\end{array}$ \\
\hline $\begin{array}{l}\text { Andrew and } \\
\text { Mitrokhin } 1999\end{array}$ & $\begin{array}{l}\text { When former KGB archivist Vasili Mitrokhin defected to } \\
\text { the United Kingdom, he brought with him a vast } \\
\text { collection of copied KGB archival documents. This } \\
\text { landmark study has valuable information on Soviet } \\
\text { foreign intelligence operations to collect scientific and } \\
\text { technological information (Directorate T and Line X). It } \\
\text { also demonstrates the limitations of the Soviet system in } \\
\text { integrating plundered technology. }\end{array}$ \\
\hline $\begin{array}{l}\text { Weinstein and } \\
\text { Vassiliev } 1999\end{array}$ & $\begin{array}{l}\text { This major work derives from rare access to KGB } \\
\text { archives. It contains some details on early Soviet military- } \\
\text { industrial espionage in the United States during the } \\
\text { 1930s. }\end{array}$ \\
\hline Sibley 1999 & $\begin{array}{l}\text { Sibley explores how Soviet spies in the } 1930 \text { s and } 1940 \text { s } \\
\text { provided Moscow with intelligence on military } \\
\text { electronics, steel production, submarine technology, } \\
\text { chemicals, aircraft, radar, and other subjects. }\end{array}$ \\
\hline
\end{tabular}




\begin{tabular}{|l|l|}
\hline Jackson 2000 & $\begin{array}{l}\text { This study documents the Eisenhower administration's } \\
\text { role in the reformulation of U.S. embargo policies and } \\
\text { shows how Winston Churchill played a key role in driving } \\
\text { the loosening of U.S. export controls. }\end{array}$ \\
\hline Macrakis 2004 & $\begin{array}{l}\text { Macrakis provides a detailed account of the Stasi's } \\
\text { industrial espionage campaign against the United States, } \\
\text { West Germany, and other allied countries during the Cold } \\
\text { War. She emphasizes that even when the Stasi was able } \\
\text { to acquire valuable intelligence, the East German state } \\
\text { could not necessarily implement the acquired technology } \\
\text { effectively. The reliance upon theft also led to } \\
\text { dependence and disincentivized domestic innovation. }\end{array}$ \\
\hline Engel 2005 & $\begin{array}{l}\text { Engel discusses the "China Differential" and differing } \\
\text { British and U.S. views on foreign economic policy toward } \\
\text { China during the Cold War. He argues that tougher U.S. } \\
\text { views and harsher embargo policies resulted from the } \\
\text { belief that economic hardship "might so pain the Chinese } \\
\text { people that they would rise up in revolt against their own } \\
\text { regime." Conversely, Engel writes, the United Kingdom } \\
\text { believed that trade would not only benefit British } \\
\text { businesses, but that "[M]ounting satisfaction among an } \\
\text { increasingly affluent Chinese populace might help temper } \\
\text { their government's more belligerent tendencies." }\end{array}$ \\
\hline $\begin{array}{l}\text { Dobson analyzes the Reagan administration's economic } \\
\text { policies toward the Soviet Union, showing that they were } \\
\text { not always as stringent as some officials' rhetoric implied. } \\
\text { While hardliners initially held greater influence in pushing } \\
\text { tough policies, moderates eventually gained sway. } \\
\text { Dobson stresses that Reagan personally aimed to } \\
\text { negotiate with the Soviet Union, not to topple it; there } \\
\text { was no "overarching strategy to implement all-out cold } \\
\text { economic warfare." }\end{array}$ \\
\hline abson
\end{tabular}




\begin{tabular}{|c|c|}
\hline Macrakis 2008 & $\begin{array}{l}\text { Macrakis uses archival documents to explore the Stasi's } \\
\text { sophisticated and often successful efforts to acquire } \\
\text { foreign technology. }\end{array}$ \\
\hline Lu 2008 & $\begin{array}{l}\text { Lu details how the U.S. embargo against China during } \\
\text { the Cold War led Washington to attempt to block } \\
\text { Indonesian rubber exports to China. }\end{array}$ \\
\hline Dobson 2010 & $\begin{array}{l}\text { Dobson reviews the history of U.S. export controls } \\
\text { against the Soviet Union. Although the embargo initially } \\
\text { had distinct strategic aims, Washington realized by the } \\
1960 \text { s that the measures were largely ineffective at } \\
\text { "hindering the Soviet Union's war-making capacity." The } \\
\text { embargo thereafter served mostly symbolic purposes, } \\
\text { besides during the early years of the Reagan } \\
\text { administration. }\end{array}$ \\
\hline Long 2018 & $\begin{array}{l}\text { This is a review of recent academic studies on the } \\
\text { perennial question of U.S. intelligence analysis of the } \\
\text { Soviet economy during the Cold War. Long notes that } \\
\text { "[B]y the mid- } 1980 \text { s, policymakers were well-informed } \\
\text { that the Soviet defense burden was becoming } \\
\text { unsustainable." He also considers the role of } \\
\text { Washington's counterintelligence and export control } \\
\text { efforts. }\end{array}$ \\
\hline $\begin{array}{l}\text { Jensen-Eriksen } \\
2019\end{array}$ & $\begin{array}{l}\text { A case study of Finland as a neutral state caught in the } \\
\text { middle of the Cold War. Jensen-Eriksen traces the role of } \\
\text { Finland in the U.S. effort to curb reexports of strategic } \\
\text { technology to the Soviet Union. His article covers export } \\
\text { control controversies involving Nokia and submarines, } \\
\text { showing how Washington pressured Helsinki as Finnish } \\
\text { policymakers sought to balance between the } \\
\text { superpowers. }\end{array}$ \\
\hline
\end{tabular}




\begin{tabular}{|l|l|}
\hline French 2020 & $\begin{array}{l}\text { This long-form article explores the life and work of Gus } \\
\text { Weiss, who played a notable role in U.S. economic } \\
\text { warfare and technology transfer policies during the Cold } \\
\text { War. It examines notable incidents such as the Farewell } \\
\text { Dossier and the mythical Siberian pipeline sabotage } \\
\text { incident. }\end{array}$ \\
\hline Colbourn 2020 & $\begin{array}{l}\text { Colbourn explores NATO's internecine tensions in the } \\
\text { early 1980s over American sanctions against a Soviet } \\
\text { pipeline. She highlights the United Kingdom and } \\
\text { Canada's attempts to help resolve the quarrel. }\end{array}$ \\
\hline
\end{tabular}




\section{Strategic Economic Competition and Export Controls after the Cold War}

COCOM may not have lived long after the end of the Cold War, but the debate over export controls continued after the fall of the Berlin Wall. As the United States found itself at the head of a unipolar world, questions of national security and economic competitiveness became increasingly relevant. For example, observers pondered whether the need to maintain U.S. technology companies' dominant position outweighed the imperative to keep cutting-edge supercomputers out of adversaries' grasp. This section includes post-Cold War writings discussing export controls on a variety of sensitive products, from encryption software to GPS. Of particular interest are export controls on space-related technologies, intended to counter China's space and ballistic missile programs. This section also includes sources analyzing COCOM's successor, the Wassenaar Arrangement.

Table 3: Selected Publications on Strategic Economic Competition and Export Controls after the Cold War

\begin{tabular}{|l|l|}
\hline Publication & Summary \\
\hline Webster 1989 & $\begin{array}{l}\text { Director of Central Intelligence William H. Webster } \\
\text { acknowledges "a universal recognition that economic } \\
\text { strength is key to global influence and power." He notes } \\
\text { that "Our political and military allies are also our } \\
\text { economic competitors" and discusses the trade deficit } \\
\text { and technological competition with Japan. }\end{array}$ \\
\hline Moran 1990 & $\begin{array}{l}\text { Moran warns of the dangers to the United States' } \\
\text { defense-industrial base as a result of globalization, } \\
\text { declaring that "[T]he contemporary movement toward } \\
\text { globalization opens the door in peacetime to foreign } \\
\text { influence, foreign control, and foreign domination." He } \\
\text { discusses the neo-mercantilist outlook on globalization }\end{array}$ \\
\hline
\end{tabular}




\begin{tabular}{|c|c|}
\hline & $\begin{array}{l}\text { and defense industries, which focuses on "nationality of } \\
\text { firms" and "location of production sites." }\end{array}$ \\
\hline Oliver 1992 & $\begin{array}{l}\text { Oliver details the problem of economic espionage, } \\
\text { describing its underlying drivers and methods. She also } \\
\text { suggests that "many Americans" are especially } \\
\text { susceptible to the threat due to being talkative, } \\
\text { ambitious, and sometimes lacking foreign language skills. }\end{array}$ \\
\hline Davis 1994 & $\begin{array}{l}\text { In her testimony to Congress, the under secretary of state } \\
\text { for international security affairs describes how sweeping } \\
\text { global changes demand reforms to U.S. export control } \\
\text { regulations. She describes the efforts to create a } \\
\text { successor to COCOM and outlines the draft Export } \\
\text { Administration Act. }\end{array}$ \\
\hline Evans 1994 & $\begin{array}{l}\text { This article reviews export controls on encryption } \\
\text { software, the regulatory process, and policy debates. } \\
\text { Evans argues that "[M]ass-market encryption software is } \\
\text { not enough of a threat to the security of the United } \\
\text { States to justify current export controls ... [It] should be } \\
\text { restricted only under the mechanisms currently } \\
\text { established for most software products." }\end{array}$ \\
\hline Tarlowe 1995 & $\begin{array}{l}\text { Tarlowe discusses the liberalization of U.S. export } \\
\text { controls toward Russia, contending that Washington } \\
\text { must "limit deregulating export controls to Russia } \\
\text { because ... [its] . . current state ... continues to pose } \\
\text { threats to U.S. security interests." }\end{array}$ \\
\hline Lachow 1995 & $\begin{array}{l}\text { RAND Corporation analyst Irving Lachow explores GPS, } \\
\text { GPS technological proliferation, and military implications. } \\
\text { He notes that there are some economic benefits to U.S. } \\
\text { international leadership in GPS, and that the United } \\
\text { States is attempting to control GPS dissemination (via } \\
\text { the Standard Positioning Service), but the controls are } \\
\text { likely inadequate. Lachow also observes that "GPS is a }\end{array}$ \\
\hline
\end{tabular}




\begin{tabular}{|c|c|}
\hline & $\begin{array}{l}\text { dual-use system by design; no previous technology has } \\
\text { provided such significant benefits to both military and } \\
\text { civilian users simultaneously." }\end{array}$ \\
\hline Arquilla 1996 & $\begin{array}{l}\text { Arquilla discusses export control policies on high- } \\
\text { performance computers, considering strategic trade-offs } \\
\text { and using historical examples. He concludes that "[A] } \\
\text { hybrid policy, mixing open and closed elements, has the } \\
\text { best chance to foster commercial competitiveness } \\
\text { without unduly compromising the national security." }\end{array}$ \\
\hline $\begin{array}{l}\text { Cupitt and } \\
\text { Grillot } 1997\end{array}$ & $\begin{array}{l}\text { This scholarly article reviews COCOM and its successor, } \\
\text { the Wassenaar Arrangement, through an international } \\
\text { relations theoretical perspective to determine why } \\
\text { multilateral cooperation increased after } 1989 \text {. The } \\
\text { authors "find that the emergence of a liberal community } \\
\text { identity among COCOM members" best explains this } \\
\text { phenomenon. }\end{array}$ \\
\hline $\begin{array}{l}\text { Bonomo et al. } \\
1998\end{array}$ & $\begin{array}{l}\text { This monograph cautions that "[l]t is extremely difficult to } \\
\text { estimate the financial effect... [of] technology transfers } \\
\ldots \text { on the United States." The authors also warn of the } \\
\text { hazards of curbing technology transfer and include a } \\
\text { study of the optoelectronics sector. }\end{array}$ \\
\hline Johnston 1998 & $\begin{array}{l}\text { Johnston reviews U.S. export controls on high } \\
\text { performance computers from } 1989 \text { onwards, considering } \\
\text { regulatory standards and debates between trade and } \\
\text { nonproliferation advocates. He also chronicles } \\
\text { controversies sparked by computer diversions in Russia } \\
\text { and China for military purposes. }\end{array}$ \\
\hline $\begin{array}{l}\text { Craft and } \\
\text { Grillot } 1999\end{array}$ & $\begin{array}{l}\text { Craft and Grillot offer a gloomy view of the Wassenaar } \\
\text { Arrangement, arguing that the inadequacies of the } \\
\text { American, British, French, and German export control } \\
\text { systems bode poorly for the institution. }\end{array}$ \\
\hline
\end{tabular}




\begin{tabular}{|c|c|}
\hline Lipson 1999 & $\begin{array}{l}\text { This article offers a historical overview and theoretical } \\
\text { analysis of the Wassenaar Arrangement, arguing that } \\
\text { constructivism best explains Wassenaar. Lipson } \\
\text { concludes that "[C]onstructivism can account for ... the } \\
\text { main organizational features of the WA." }\end{array}$ \\
\hline $\begin{array}{l}\text { Howes and } \\
\text { Singh } 2000\end{array}$ & $\begin{array}{l}\text { This edited volume covers a variety of economic topics, } \\
\text { including the U.S. trade deficit, the discussion over } \\
\text { crafting effective industrial and technology policy, and } \\
\text { how to revitalize the U.S. manufacturing sector. }\end{array}$ \\
\hline Grimmett 2001 & $\begin{array}{l}\text { Grimmett provides an overview of export controls on } \\
\text { encryption products, as well as discussion of } \\
\text { legal/constitutional issues and proposed legislation. }\end{array}$ \\
\hline $\begin{array}{l}\text { U.S. Congress } \\
2001\end{array}$ & $\begin{array}{l}\text { Experts from the General Accounting Office discuss } \\
\text { recent changes to the export control framework } \\
\text { concerning high-performance computers. They cover } \\
\text { technical details, the role of the Wassenaar Arrangement, } \\
\text { and more. }\end{array}$ \\
\hline Kan 2001 & $\begin{array}{l}\text { A detailed chronology of U.S.-China export control } \\
\text { controversies regarding satellites, from the Loral/Hughes } \\
\text { and Long March cases to the Cox Report. }\end{array}$ \\
\hline $\begin{array}{l}\text { McLoughlin } \\
\text { and Fergusson } \\
2005\end{array}$ & $\begin{array}{l}\text { This report reflects perennial issues in export control } \\
\text { debates, including discussions of economic harm versus } \\
\text { national security interests and the obsolescence of } \\
\text { regulatory standards. It also includes background and a } \\
\text { history of export controls on high performance } \\
\text { computers. }\end{array}$ \\
\hline $\begin{array}{l}\text { Van Atta et al. } \\
2007\end{array}$ & $\begin{array}{l}\text { This massive study fails to find convincing evidence that } \\
\text { export controls are hurting the U.S. market share in } \\
\text { satellites and machine tools. However, the effects may be }\end{array}$ \\
\hline
\end{tabular}




\begin{tabular}{|c|c|}
\hline & $\begin{array}{l}\text { more subtle, and there is a risk of export controls } \\
\text { diminishing U.S. firms' competitiveness-including } \\
\text { through "ITAR-tainting." Similarly, semiconductor firms } \\
\text { did not suffer from export controls, but they could be } \\
\text { affected by expanded export controls. However, the } \\
\text { report concludes that "The current US export control } \\
\text { system appears to be out of step with today's world of } \\
\text { global manufacturing, technology development, and } \\
\text { capital flows." }\end{array}$ \\
\hline $\begin{array}{l}\text { Galama and } \\
\text { Hosek } 2008\end{array}$ & $\begin{array}{l}\text { This report counters some pessimistic views of U.S. } \\
\text { international competitiveness in science and technology, } \\
\text { examining areas such as education, workforce, research } \\
\text { and development investment, employment, and patents. } \\
\text { The authors conclude that "[T]he U.S. S\&T enterprise is } \\
\text { performing well... [T]he United States leads the world } \\
\text { in S\&T and has kept pace or grown faster than the rest of } \\
\text { the world in many measures of S\&T." The study } \\
\text { recommends immigration reform, increased international } \\
\text { scientific and technological collaboration and exchange, } \\
\text { and improved education. }\end{array}$ \\
\hline $\begin{array}{l}\text { Center for } \\
\text { Strategic and } \\
\text { International } \\
\text { Studies } 2008\end{array}$ & $\begin{array}{l}\text { This briefing is a negative appraisal of space-focused } \\
\text { export controls: "The grand strategic intent of the space } \\
\text { export controls is not being achieved." The export } \\
\text { controls are hurting U.S. competitiveness, restricting } \\
\text { "access to foreign innovation and human capital," and } \\
\text { making international cooperation challenging. Foreign } \\
\text { market share in the space industry is growing steadily. } \\
\text { Moreover, the export controls could be tweaked without } \\
\text { harming national security. }\end{array}$ \\
\hline Chao 2008 & $\begin{array}{l}\text { Chao offers a review of export control and technological } \\
\text { competitiveness issues, surveying numerous think tank } \\
\text { and government studies. He argues that the "increasing } \\
\text {. volume of licenses," globalization, and technological } \\
\text { innovation/complexity demand reforms of the export } \\
\text { control system. Chao points out that control lists are }\end{array}$ \\
\hline
\end{tabular}




\begin{tabular}{|l|l|}
\hline Sargent 2008 & $\begin{array}{l}\text { outdated and inflexible, also urging greater international } \\
\text { cooperation. }\end{array}$ \\
\hline $\begin{array}{l}\text { Sargent reviews U.S. policies on nanotechnology, } \\
\text { provides statistics on global nanotechnology competition, } \\
\text { and notes different perspectives on governmental } \\
\text { involvement. He also details disagreement on whether } \\
\text { the government should pursue an active role sponsoring } \\
\text { nanotechnology development, or whether such efforts } \\
\text { are contrary to free-market values (or whether } \\
\text { nanotechnology itself is too dangerous to pursue). }\end{array}$ \\
\hline U.S. Congress & $\begin{array}{l}\text { This hearing features testimony from academics and } \\
\text { scientists describing how export controls impede } \\
\text { research involving foreign nationals and certain sensitive } \\
\text { sectors, thus harming the United States' human capital. } \\
\text { The testimony also describes the detrimental impacts on } \\
\text { high-tech manufacturing. }\end{array}$ \\
\hline Kuntz 2013 & $\begin{array}{l}\text { Kuntz asserts that the low number of convictions secured } \\
\text { under the Economic Espionage Act of 1996 is the result } \\
\text { of "narrow judicial interpretation." She also notes that } \\
\text { "[T]he EEA does not punish or deter the roots of the } \\
\text { problem: foreign governments that solicit and benefit } \\
\text { from economic espionage." }\end{array}$ \\
\hline $\begin{array}{l}\text { The authors critique the Economic Espionage Act of } \\
\text { 1996, arguing that it may dampen the innovation needed } \\
\text { for American economic competitiveness. }\end{array}$ \\
\hline abel
\end{tabular}


Economic and Technological Competition: U.S.-Japan

Although trade tensions between the United States and Japan were hardly new at the time, the 1980s saw the emergence of profound concern in Washington over the economic rise of Japan and its potential to overtake the United States. Much literature focused on diagnosing the root causes of the economic conflict, from statist development policies and exchange rates to declining U.S. competitiveness and different economic philosophies. Some warned of calamity - such as the outright collapse of the free-trade system-or offered deeply pessimistic forecasts of "U.S. decline and dependence on Japan," as technology researcher Charles $\mathrm{H}$. Ferguson put it. To be sure, other analysts counseled moderation and suggested more modest outcomes. The latter were effectively vindicated when the Japanese economic bubble popped in the early 1990s. More recently, observers have compared the earlier Japan scare with the contemporary China challenge, pointing out key similarities and differences between the two phenomena and attempting to discern lessons learned.

Table 4: Selected Publications on Economic and Technological Competition: U.S.-Japan

\begin{tabular}{|l|l|}
\hline Publication & Summary \\
\hline Ogata 1980 & $\begin{array}{l}\text { Ogata reviews Japan's economic history and relations } \\
\text { with Washington, writing that "[T]he relationship ... has } \\
\text { undergone considerable strain because of recurring } \\
\text { economic disputes." }\end{array}$ \\
\hline Basiuk 1982 & $\begin{array}{l}\text { This study focuses on Japan and Europe and assesses } \\
\text { U.S. competitiveness in electronics, computers, and } \\
\text { machine tools. Basiuk describes Japan as the larger } \\
\text { challenge, particularly in semiconductors and computers; } \\
\text { another problem is U.S. defense dependence upon } \\
\text { Japanese technology. Basiuk warns that "If present } \\
\text { trends continue ... the Japanese will take over leadership }\end{array}$ \\
\hline
\end{tabular}




\begin{tabular}{|c|c|}
\hline & $\begin{array}{l}\text { from the United States in a number of key areas of } \\
\text { power-relevant technology ... [B]y the year } 2000, \text { a } \\
\text { significant change in the world balance of power will take } \\
\text { place." }\end{array}$ \\
\hline Bergsten 1982 & $\begin{array}{l}\text { Bergsten assesses the various theories purporting to } \\
\text { explain "U.S.-Japanese economic conflict," including } \\
\text { Japanese protectionism; "periodic export surges ... } \\
\text { benefit[ting] "unfairly' from government support and } \\
\text { exclusion of foreign competition"; Japan's savings } \\
\text { prompting capital export problems; "Lagging Japanese } \\
\text { economic growth ... [causing] major export offensives"; } \\
\text { declining U.S. productivity and rising inflation; and } \\
\text { "exchange-rate misalignment." The author ultimately } \\
\text { concludes that the latter is the key underlying factor. }\end{array}$ \\
\hline Okita 1982 & $\begin{array}{l}\text { Japan's former foreign minister counters U.S. charges of } \\
\text { unfair trade practices and Washington's concerns over } \\
\text { the trade deficit. He suggests that "[H]igh U.S. interest } \\
\text { rates ... in combination with U.S. inflation have } \\
\text { undervalued the yen and overvalued the dollar," leading } \\
\text { to export disputes. }\end{array}$ \\
\hline $\begin{array}{l}\text { Cabinet Council } \\
\text { on Commerce } \\
\text { and Trade } \\
1982\end{array}$ & $\begin{array}{l}\text { This report touches on major factors important for } \\
\text { technological competitiveness, including the domestic } \\
\text { economy, capital cost and supply, research and } \\
\text { development, technology transfer, human capital, and } \\
\text { industrial policies. It warns of state-driven and } \\
\text { protectionist policies-especially by Japan-that are } \\
\text { harming U.S. market share in high-technology industries. }\end{array}$ \\
\hline $\begin{array}{l}\text { Office of } \\
\text { Technology } \\
\text { Assessment } \\
1983\end{array}$ & $\begin{array}{l}\text { This research report focuses on color TVs, } \\
\text { semiconductors, and computers. It finds that U.S. } \\
\text { electronics firms are overall performing strongly but are } \\
\text { under increasing pressure from Japan. Competitiveness in } \\
\text { consumer electronics "has declined precipitously since } \\
\text { the } 1960 \text { 's." In computers and semiconductors, U.S. }\end{array}$ \\
\hline
\end{tabular}




\begin{tabular}{|c|c|}
\hline & $\begin{array}{l}\text { companies are in better shape. The report offers a range } \\
\text { of industrial policy options, including education, research } \\
\text { and development investment, and economic reforms. }\end{array}$ \\
\hline $\begin{array}{l}\text { Caccamise et } \\
\text { al. } 1983\end{array}$ & $\begin{array}{l}\text { This study of U.S. military dependency on foreign- } \\
\text { produced semiconductors is particularly concerned with } \\
\text { the rising Japanese semiconductor market and the lack of } \\
\text { military accounting for its use of foreign semiconductors. }\end{array}$ \\
\hline $\begin{array}{l}\text { Zysman and } \\
\text { Cohen } 1983\end{array}$ & $\begin{array}{l}\text { Zysman and Cohen discuss challenges to the } \\
\text { international free trade system, including the (Japanese) } \\
\text { developmental state, state-managed surplus, "state } \\
\text { trading and barter," and U.S. industrial decline. The } \\
\text { authors warn of "a real struggle about international } \\
\text { economic position and the economic role of the state... } \\
\text { [that] will result in an unmanageable burst of } \\
\text { mercantilism that will undermine the liberal system and } \\
\text { threaten the stability of the international political order." }\end{array}$ \\
\hline Hatter 1985 & $\begin{array}{l}\text { This report analyzes international competition in high- } \\
\text { tech trade, particularly the involvement of Japan and } \\
\text { Europe in the electronics, aircraft, chemical, and materials } \\
\text { industries. }\end{array}$ \\
\hline Johnson 1987 & $\begin{array}{l}\text { Johnson writes that Japanese "institutions of capitalism } \\
\text {... differ fundamentally from those encountered in } \\
\text { American capitalism." In his view, Americans see the } \\
\text { market "as a source of efficiency," while Japan sees the } \\
\text { market "as a source of growth." This is the root cause of } \\
\text { tensions between the United States and Japan. Johnson } \\
\text { advocates better STEM training, better trade policy, and } \\
\text { economic reforms, as well as "open[ing] Japan's } \\
\text { markets." }\end{array}$ \\
\hline Ferguson 1989 & $\begin{array}{l}\text { Ferguson proclaims that " }[T] \text { he long-term structural } \\
\text { patterns of U.S.-Japanese interaction in finance and high } \\
\text { technology imply a future of U.S. decline and dependence }\end{array}$ \\
\hline
\end{tabular}




\begin{tabular}{|c|c|}
\hline & $\begin{array}{l}\text { on Japan." He claims that the U.S. technological decline } \\
\text { stems from parochial domestic institutions and foreign } \\
\text { competition. Ferguson insists that the United States must } \\
\text { pursue both "internal reform and ... the management of } \\
\text { a new strategic balance, namely its technological } \\
\text { competition with Japan. If America fails it will encounter } \\
\text { something approaching an economic crisis." }\end{array}$ \\
\hline Fallows 1989 & $\begin{array}{l}\text { Fallows believes that Japan's economic practices pose a } \\
\text { serious challenge to the United States. In his eyes, the } \\
\text { Japanese economy is fundamentally different from that of } \\
\text { the United States, leading to major trade disputes and } \\
\text { fears of Japanese economic hegemony. }\end{array}$ \\
\hline $\begin{array}{l}\text { Joint Economic } \\
\text { Committee } \\
1990\end{array}$ & $\begin{array}{l}\text { This lengthy volume contains more than } 30 \text { papers on a } \\
\text { variety of topics, including Japanese industrial policies, } \\
\text { foreign investment, demographics, science and } \\
\text { technology, and trade. The introduction states that } \\
\text { "Japan's economic challenge to the United States differs } \\
\text { from any other challenge that the Nation has faced } \\
\text { during the past century.... The challenge is not of life } \\
\text { and death proportions, yet it affects the daily affairs of } \\
\text { Americans in ways that are both obvious and insidious." }\end{array}$ \\
\hline $\begin{array}{l}\text { Office of } \\
\text { Technology } \\
\text { Assessment } \\
1991\end{array}$ & $\begin{array}{l}\text { This is a sober account of declining U.S. competitiveness, } \\
\text { especially vis-à-vis Japan. It discusses the notable role of } \\
\text { state-driven industrial policies by international } \\
\text { competitors. Case studies include the supercomputer and } \\
\text { aircraft industries, and European countries' responses to } \\
\text { Japan are also detailed. The report suggests policy } \\
\text { options for confronting the problem, including public- } \\
\text { private partnerships in research and development, trade } \\
\text { policy measures, and human capital cultivation. }\end{array}$ \\
\hline Zysman 1991 & $\begin{array}{l}\text { Zysman argues that U.S. industrial and economic decline } \\
\text { has led to a multipolar economic system, which will in } \\
\text { turn create a "multipolar security system" centered on }\end{array}$ \\
\hline
\end{tabular}




\begin{tabular}{|c|c|}
\hline & $\begin{array}{l}\text { Japan, the United States, and the European Community. } \\
\text { He discusses trade patterns, economic development } \\
\text { strategies, and military and civilian research and } \\
\text { development. In Zysman's estimation, "As economic } \\
\text { power increases in importance, the basis for influence } \\
\text { shifts from the domain of military force, where America } \\
\text { remains strong, to the domain of economics, where its } \\
\text { position is weakened." }\end{array}$ \\
\hline $\begin{array}{l}\text { Mastanduno } \\
1991\end{array}$ & $\begin{array}{l}\text { Mastanduno reviews American policies vis-à-vis Japan } \\
\text { regarding the FSX aircraft controversy, satellites, and } \\
\text { high-definition televisions. He concludes that policy } \\
\text { debates resulting from "[economic] relative gains } \\
\text { concerns" were influenced by "ideology and the } \\
\text { institutional setting." }\end{array}$ \\
\hline $\begin{array}{l}\text { Nye } \\
\text { 1992/1993 }\end{array}$ & $\begin{array}{l}\text { Nye offers a more nuanced view on the Japanese } \\
\text { economic challenge to the United States. However, he } \\
\text { points out that perceptions of U.S. decline and Japanese } \\
\text { ascendance are influential whether or not they are } \\
\text { accurate. He concludes by exploring ways in which Japan } \\
\text { could leverage its power for the global good. }\end{array}$ \\
\hline Tyson 1993 & $\begin{array}{l}\text { This work includes case studies of the controversies over } \\
\text { the Japanese consumer electronics and semiconductor } \\
\text { industries, as well as European competition in electronics } \\
\text { and aircraft. Tyson advocates a policy of "cautious } \\
\text { activism" that is nevertheless far from outright } \\
\text { protectionism. }\end{array}$ \\
\hline $\begin{array}{l}\text { Mastanduno } \\
2000\end{array}$ & $\begin{array}{l}\text { Mastanduno describes the rise and fall of the Japanese } \\
\text { economic challenge to the United States. He also } \\
\text { considers "the end of the Washington consensus ... and } \\
\text { the renewal of US hegemony." }\end{array}$ \\
\hline Morris 2011 & $\begin{array}{l}\text { Morris provides a full account of U.S. anxiety during the } \\
\text { 1980s over Japan's economic ascendance, tracing the }\end{array}$ \\
\hline
\end{tabular}




\begin{tabular}{|c|c|}
\hline & $\begin{array}{l}\text { evolution of "Japan-bashing" in the media, public opinion, } \\
\text { and policy circles. She also considers the phenomenon's } \\
\text { cultural impact and legacy. }\end{array}$ \\
\hline Lohr 2011 & $\begin{array}{l}\text { This article compares the } 1980 \text { s Japan economic scare } \\
\text { with the contemporary China challenge. Lohr points out } \\
\text { that the latter is more significant than the former was in } \\
\text { important aspects, such as greater U.S. economic } \\
\text { entanglement. }\end{array}$ \\
\hline Miller 2017 & $\begin{array}{l}\text { Miller explains "the fear that Japan had beaten the United } \\
\text { States at its own game" of free trade. This concern was } \\
\text { based on arguments that the United States was being } \\
\text { overtaken by an economic rival that held different values, } \\
\text { pursued different policies, and took advantage of the } \\
\text { American-established global economic order. }\end{array}$ \\
\hline Foot 2017 & $\begin{array}{l}\text { Foot provides a brief history of the U.S.-Japan } \\
\text { confrontation in the } 1970 \text { s and } 1980 \text { s alongside the } \\
\text { confrontations with China from the } 1970 \text { s and } 1990 \text { s. } \\
\text { She assesses that despite some similarities in the United } \\
\text { States' relations with China today and Japan previously, } \\
\text { "[T]he differences in the military and strategic dimension } \\
\text { of the US-China relationship... distinguish it from the } \\
\text { US response to the Japan challenge." }\end{array}$ \\
\hline Landers 2018 & $\begin{array}{l}\text { Landers compares the ongoing U.S. trade war with China } \\
\text { with Washington's trade disputes with Japan in the } \\
\text { 1980s. He highlights how although Reagan obtained } \\
\text { some concessions from Tokyo, these contributed to the } \\
\text { eventual destabilization of the Japanese economy. }\end{array}$ \\
\hline Tan 2018 & $\begin{array}{l}\text { Tan compares U.S. attempts to counter China's "Made in } \\
\text { China 2025" program with previous efforts to gain } \\
\text { economic concessions from Japan in the } 1980 \text { s. She } \\
\text { contends that the determining factor is how pressure } \\
\text { impacts domestic groups, concluding that "[C] ]urrent U.S. }\end{array}$ \\
\hline
\end{tabular}




\begin{tabular}{|l|l|}
\hline Urata 2020 & $\begin{array}{l}\text { demands effectively strengthen the hand of Chinese } \\
\text { agencies and officials who oppose market liberalization." }\end{array}$ \\
\hline $\begin{array}{l}\text { Urata surveys U.S. trade disputes with Japan, which } \\
\text { extended as far back as the 1950s and involved products } \\
\text { such as textiles, steel, cars, and semiconductors. He } \\
\text { notes similarities and differences compared to the } \\
\text { contemporary China challenge; the political challenges } \\
\text { are far more significant today, and the United States is } \\
\text { more intertwined with China than it was with Japan. }\end{array}$ \\
\hline
\end{tabular}


Strategic, Economic, and Technological Competition: U.S.-China

The ascendance of China as a twenty-first-century global power and its economic and technological challenges to the United States have generated a colossal and growing literature. This section surveys some of the key points, including the contemporary history of U.S. export controls and technology transfer regulations toward China and China's technonationalist policies. Much of the literature analyzes China's technology transfer methods, its future prospects in its ongoing competition with the United States, and Beijing's use of economic statecraft. A range of technologies is discussed in this context, from aircraft and artificial intelligence to autonomous vehicles and mobile data networks. More recently, as discussion of U.S.-China "decoupling" has grown, observers have generally agreed that some decoupling might be beneficial for U.S. security, but wholesale detachment would be impossible and economically destructive. Numerous analyses have explored how decoupling might proceed.

Table 5: Selected Publications on Strategic, Economic, and Technological Competition: U.S.-China

\begin{tabular}{|l|l|}
\hline Publication & Summary \\
\hline $\begin{array}{l}\text { CIA Directorate } \\
\text { of Intelligence } \\
1983\end{array}$ & $\begin{array}{l}\text { This CIA intelligence report assesses China's economy, } \\
\text { concluding that human capital limitations, lack of } \\
\text { incentives, planning difficulties, and military-focused } \\
\text { priorities impede China's use of foreign technology. }\end{array}$ \\
\hline Nimmo 1984 & $\begin{array}{l}\text { Nimmo reviews U.S. export control/technology transfer } \\
\text { policies toward China, policy debates, institutions, and } \\
\text { Reagan-era developments. She notes the dilemma } \\
\text { between accruing trade benefits by conducting business } \\
\text { with China and supplying a potential adversary with } \\
\text { useful technologies and goods. }\end{array}$ \\
\hline
\end{tabular}




\begin{tabular}{|c|c|}
\hline Chiang 1987 & $\begin{array}{l}\text { Chiang states that if China uses advanced foreign } \\
\text { technology for economic development, it poses little } \\
\text { threat because the country is far behind on this front. } \\
\text { However, if China uses technology for military purposes, } \\
\text { it could pose a significant challenge. }\end{array}$ \\
\hline Yuan 1996 & $\begin{array}{l}\text { Yuan chronicles U.S. export controls toward China from } \\
\text { 1989. He details Washington's restrictions on trade, } \\
\text { technology transfer, and other economic exchanges } \\
\text { following Tiananmen; proliferation sanctions; and } \\
\text { influences on policy, such as economic interests, the aim } \\
\text { to engage China, and the challenges of national and } \\
\text { multilateral export controls. Yuan finds that the key factor } \\
\text { behind technology transfer policy regarding China is } \\
\text { "concern over the direction and stability of post-Cold } \\
\text { War bilateral relations and how to manage them in } \\
\text { changing domestic and external environments." }\end{array}$ \\
\hline $\begin{array}{l}\text { U.S. Congress } \\
1999\end{array}$ & $\begin{array}{l}\text { The controversial and influential Cox Report examines } \\
\text { Chinese government acquisition of key U.S. technologies, } \\
\text { ranging from nuclear weapons data and computers to } \\
\text { rocket technology. }\end{array}$ \\
\hline $\begin{array}{l}\text { Papayoanou } \\
\text { and Kastner } \\
1999 / 2000\end{array}$ & $\begin{array}{l}\text { The authors write that engaging China "empowers more } \\
\text { cooperative economic internationalists ... while a rigid } \\
\text { containment policy would probably weaken those forces } \\
\text { and might bring to the fore more conflictual political and } \\
\text { economic interests." They add that limited U.S. economic } \\
\text { interests in China will not hamper Washington if the } \\
\text { U.S.-China relationship becomes more confrontational. } \\
\text { The article includes case studies of French-Russian } \\
\text { relations around the turn of the twentieth century and } \\
\text { Germany's economic relations prior to World War I. }\end{array}$ \\
\hline $\begin{array}{l}\text { Feigenbaum } \\
2000\end{array}$ & $\begin{array}{l}\text { Feigenbaum analyzes the history of Chinese } \\
\text { technonationalist industrial policy, from Mao to the }\end{array}$ \\
\hline
\end{tabular}




\begin{tabular}{|c|c|}
\hline & $\begin{array}{l}\text { present day. He notes the emphasis on technological } \\
\text { acquisition and indigenization, but considers their } \\
\text { limitations (the tendency to "leapfrog" and the necessity } \\
\text { of integrating in order to indigenize). }\end{array}$ \\
\hline Segal 2004 & $\begin{array}{l}\text { Amidst concerns over American trade in sensitive goods } \\
\text { with China, Segal advises "maintain[ing] the embargo on } \\
\text { the sale of military items and a small but very crucial } \\
\text { handful of dual-use items, while relaxing controls on } \\
\text { most advanced commercial technologies." He points to } \\
\text { the need to keep U.S. firms competitive, also arguing that } \\
\text { Chinese dependence on American technology is } \\
\text { advantageous for Washington. }\end{array}$ \\
\hline Suttmeier 2004 & $\begin{array}{l}\text { Suttmeier outlines differing views on China's } \\
\text { technological prospects, from skepticism to deep } \\
\text { concern. He emphasizes the role of Beijing and its } \\
\text { "techno-nationalist vision of using political power to } \\
\text { advance scientific and technological development." }\end{array}$ \\
\hline Gilboy 2004 & $\begin{array}{l}\text { Gilboy argues that the United States has successfully } \\
\text { engaged China and helped it become a stakeholder in the } \\
\text { international economic system. Moreover, the country } \\
\text { remains reliant "on foreign technology and investment," } \\
\text { which limits its potential threat. Gilboy analyzes the } \\
\text { Chinese economy and Chinese technological innovation, } \\
\text { advocating "strategic engagement ... to bolster U.S. } \\
\text { technological, economic, and political leadership." }\end{array}$ \\
\hline Drezner 2009 & $\begin{array}{l}\text { Drezner scrutinizes claims that Beijing could use its } \\
\text { holdings of U.S. debt as a tool of economic influence. } \\
\text { Reviewing the literature on economic coercion, Drezner } \\
\text { asserts that "[T] he power of credit between great powers } \\
\text { has been exaggerated in policy circles." His article also } \\
\text { includes a detailed study of China's involvement in the } \\
2008 \text { financial crisis. }\end{array}$ \\
\hline
\end{tabular}




\begin{tabular}{|c|c|}
\hline Friedberg 2010 & $\begin{array}{l}\text { Friedberg lays out a preliminary assessment of the } \\
\text { impact of the Great Recession on U.S.-China relations. He } \\
\text { suggests that "[E]conomic issues are likely to become a } \\
\text { source of increasing friction... The belief that China's } \\
\text { rise is inevitable and may be accelerating ... is likely to } \\
\text { intensify impulses toward balancing." }\end{array}$ \\
\hline $\begin{array}{l}\text { Beckley } \\
\text { 2011/2012 }\end{array}$ & $\begin{array}{l}\text { In this contrarian essay, Beckley argues against the } \\
\text { "conventional wisdom ... [that] the United States is in } \\
\text { decline relative to China ... [and that] much of this } \\
\text { decline is the result of globalization ... and the } \\
\text { hegemonic burdens the United States bears to sustain } \\
\text { [it]." He contends that conventional net assessment } \\
\text { measures, such as GDP analysis, are not helpful. In } \\
\text { Beckley's economic and demographic analyses, the } \\
\text { United States has strong advantages over China. }\end{array}$ \\
\hline $\begin{array}{l}\text { Scissors and } \\
\text { Subramanian } \\
2012\end{array}$ & $\begin{array}{l}\text { Scissors and Subramanian debate the implications of } \\
\text { China's rise, with Scissors stressing residual Chinese } \\
\text { economic weakness and Subramanian arguing that China } \\
\text { will overtake the United States within } 20 \text { years. }\end{array}$ \\
\hline $\begin{array}{l}\text { Van Reenen } \\
\text { and Yueh } 2012\end{array}$ & $\begin{array}{l}\text { The authors examine the effect of joint ventures and } \\
\text { technology transfer on China's economic growth, finding } \\
\text { that " }[\mathrm{H}] \text { ad China not attracted FDI and IJVs ... then } \\
\text { China's annual GDP growth could have been between } \\
\text { one-half to over a percentage point lower... over the } \\
\text { past } 30 \text { years." }\end{array}$ \\
\hline $\begin{array}{l}\text { Hannas, } \\
\text { Mulvenon, and } \\
\text { Puglisi } 2013\end{array}$ & $\begin{array}{l}\text { This work explores Chinese government technology } \\
\text { transfer efforts, including the bureaucratic infrastructure } \\
\text { involved and acquisition through open sources, students, } \\
\text { cyberespionage, trade, and more. }\end{array}$ \\
\hline Bräuner 2013 & $\begin{array}{l}\text { Bräuner details EU export controls against China, finding } \\
\text { that the EU views relations with China in terms of }\end{array}$ \\
\hline
\end{tabular}




\begin{tabular}{|c|c|}
\hline & $\begin{array}{l}\text { economics, rather than security. Trade, investment, and } \\
\text { scientific and technological cooperation are key } \\
\text { components of the Sino-European relationship. }\end{array}$ \\
\hline $\begin{array}{l}\text { Marukawa } \\
2013\end{array}$ & $\begin{array}{l}\text { Marukawa discusses historical Japanese export controls } \\
\text { and contemporary problems of "technology leakage." He } \\
\text { assesses that economic factors, not security needs, } \\
\text { typically shape Japanese export control and technology } \\
\text { transfer policies. }\end{array}$ \\
\hline Evron 2013 & $\begin{array}{l}\text { Evron demonstrates how U.S. pressure led Israel to take } \\
\text { a much more restrictive stance on scientific, } \\
\text { technological, and defense ties with China. Evron argues } \\
\text { that although technology transfers to China require } \\
\text { American oversight, civilian technology transfer can } \\
\text { occur. }\end{array}$ \\
\hline Weedon 2015 & $\begin{array}{l}\text { Weedon reviews the extent of Chinese government- } \\
\text { sponsored cyberespionage, which she notes } \\
\text { "consistently target[s] future growth areas" prioritized in } \\
\text { Chinese industrial strategy. She states that Chinese } \\
\text { domestic concerns, including environmental and } \\
\text { healthcare issues, may influence its cyberespionage } \\
\text { targeting. }\end{array}$ \\
\hline $\begin{array}{l}\text { Brooks and } \\
\text { Wohlforth } \\
2015 / 2016\end{array}$ & $\begin{array}{l}\text { Brooks and Wohlforth analyze military, economic, and } \\
\text { technological metrics of China's rise, arguing that while } \\
\text { "[T]he United States will long remain the only state with } \\
\text { the capability to be a superpower," China is now "an } \\
\text { emerging potential superpower." }\end{array}$ \\
\hline $\begin{array}{l}\text { Harrell, } \\
\text { Rosenberg, and } \\
\text { Saravalle } 2018\end{array}$ & $\begin{array}{l}\text { Studying Beijing's economic coercion, the authors } \\
\text { identify the different types of coercive measures used } \\
\text { and the characteristics of Chinese economic coercion. } \\
\text { They find that China is learning from the successes and } \\
\text { failures of its economic coercion efforts. }\end{array}$ \\
\hline
\end{tabular}




\begin{tabular}{|c|c|}
\hline Kania 2018 & $\begin{array}{l}\text { Kania outlines China's innovation initiatives in emerging } \\
\text { technologies, including artificial intelligence and quantum } \\
\text { technology, also discussing "Chinese investments, } \\
\text { incubators, and acquisitions focused on strategic } \\
\text { technologies." }\end{array}$ \\
\hline $\begin{array}{l}\text { Roberts, Choer } \\
\text { Moraes, and } \\
\text { Ferguson } 2018\end{array}$ & $\begin{array}{l}\text { The authors describe the emergence of strategic } \\
\text { economic competition between the United States and } \\
\text { China, as well as the intertwining of economic, } \\
\text { technological, and strategic interests. They predict the } \\
\text { rise of spheres of influence and note initial steps toward } \\
\text { decoupling. }\end{array}$ \\
\hline $\begin{array}{l}\text { Gilli and Gilli } \\
2018 / 2019\end{array}$ & $\begin{array}{l}\text { Gilli and Gilli show that "the growing complexity of } \\
\text { weapons systems" makes it extremely hard for upstarts } \\
\text { to catch up to predominant powers by replicating their } \\
\text { technology. Innovation today depends upon } \\
\text { "accumulated experience" and expertise in systems } \\
\text { integration. Moreover, it is nearly impossible to simply } \\
\text { transfer civilian capacity to military purposes, given the } \\
\text { increase in specialization and the importance of expertise } \\
\text { The article includes case studies of Imperial Germany's } \\
\text { efforts to catch up to the United Kingdom in battleships } \\
\text { and China's development of stealth fighters based on the } \\
\text { U.S. F-22 Raptor. }\end{array}$ \\
\hline $\begin{array}{l}\text { Cheung, } \\
\text { Lucyshyn, and } \\
\text { Rigilano } 2019\end{array}$ & $\begin{array}{l}\text { This paper identifies the three key steps of China's } \\
\text { technology transfer strategy: "introduction, digestion, } \\
\text { assimilation and re-innovation." The authors include case } \\
\text { studies of the Chinese aircraft industry to highlight the } \\
\text { successes and challenges of this strategy. }\end{array}$ \\
\hline $\begin{array}{l}\text { McGeachy } \\
2019\end{array}$ & $\begin{array}{l}\text { McGeachy considers China's involvement in standard- } \\
\text { setting for } 5 \mathrm{G} \text { and artificial intelligence. She advises that } \\
\text { "Washington should take a more active role in }\end{array}$ \\
\hline
\end{tabular}




\begin{tabular}{|c|c|}
\hline & $\begin{array}{l}\text { international standards-development and signal ... [its] } \\
\text { value ... in addressing growing technology competition." }\end{array}$ \\
\hline $\begin{array}{l}\text { Lim and } \\
\text { Ferguson } 2019\end{array}$ & $\begin{array}{l}\text { Lim and Ferguson point out that decoupling undermines } \\
\text { the longtime U.S. goal of using economic leverage to } \\
\text { convince China to liberalize economically. }\end{array}$ \\
\hline Toner 2019 & $\begin{array}{l}\text { Toner explains the transformative potential of artificial } \\
\text { intelligence, the dangers that "a restrictive approach" } \\
\text { poses to U.S. innovation, and the importance of data and } \\
\text { standard-setting. }\end{array}$ \\
\hline Lewis 2019 & $\begin{array}{l}\text { Lewis outlines a strategy to protect U.S. technology from } \\
\text { acquisition by China. He advises developing "new end- } \\
\text { user controls... for emerging technology," international } \\
\text { collaboration on investment screening, updated export } \\
\text { controls, and expanded counterintelligence efforts. } \\
\text { However, he cautions against restricting Chinese } \\
\text { employees and students from working and studying in } \\
\text { the United States, or imposing an outright embargo } \\
\text { against China. }\end{array}$ \\
\hline $\begin{array}{l}\text { Boustany and } \\
\text { Friedberg } 2019\end{array}$ & $\begin{array}{l}\text { This report advocates reaching a "ceasefire in the current } \\
\text { tariff war," limiting critical technology flows (in both } \\
\text { directions) and susceptibility to technological } \\
\text { vulnerabilities, domestic investment in education and } \\
\text { technology to ensure competitiveness, and international } \\
\text { engagement with allies. }\end{array}$ \\
\hline Ortega 2020 & $\begin{array}{l}\text { Ortega discusses major issues concerning the } \\
\text { technological competition involving the United States, } \\
\text { China, and Europe, including investment screening, data } \\
\text { standards, 5G, artificial intelligence, semiconductors, web } \\
\text { services, and regulation. }\end{array}$ \\
\hline
\end{tabular}




\begin{tabular}{|c|c|}
\hline $\begin{array}{l}\text { Farrell and } \\
\text { Newman } 2020\end{array}$ & $\begin{array}{l}\text { Farrell and Newman demonstrate the evolving view of } \\
\text { globalization and interdependence as weapons and } \\
\text { vulnerabilities. They write that "Under chained } \\
\text { globalization, states will be bound together by } \\
\text { interdependence that will tempt them to strangle their } \\
\text { competitors"; however, decoupling is not a viable option. }\end{array}$ \\
\hline Drezner 2020 & $\begin{array}{l}\text { Drezner complains that calls for decoupling ignore the } \\
\text { economic harm caused by the loss of comparative } \\
\text { advantage benefits from trade and offshore supply } \\
\text { chains. He is skeptical of the prospects of industrial } \\
\text { policy, given that policymakers do not understand the } \\
\text { issues at hand. }\end{array}$ \\
\hline Kennedy 2020 & $\begin{array}{l}\text { Kennedy charges that Washington's campaign against } \\
\text { Huawei might erode the U.S. technological lead in } \\
\text { semiconductors, harm U.S. security interests, and } \\
\text { "[accelerate] China's technological independence." He } \\
\text { recommends a multilateral approach to Huawei that } \\
\text { includes "fair-trade tools" and avoids wholesale } \\
\text { decoupling. }\end{array}$ \\
\hline Scissors 2020 & $\begin{array}{l}\text { Scissors offers a roadmap for how the United States } \\
\text { could decouple from China, based on economic analyses. } \\
\text { He urges a focus on Chinese state subsidies, supply } \\
\text { chain regulation, investment screening, and revamped } \\
\text { export controls. }\end{array}$ \\
\hline Xiong 2020 & $\begin{array}{l}\text { Xiong reviews recent incidents of Chinese government } \\
\text { economic coercion from Japan to Australia, noting that } \\
\text { this tactic "can backfire by prompting countries to reduce } \\
\text { their mutual dependence and accelerate the process of } \\
\text { decoupling." }\end{array}$ \\
\hline
\end{tabular}




\begin{tabular}{|c|c|}
\hline $\begin{array}{l}\text { Kania and } \\
\text { Laskai } 2021\end{array}$ & $\begin{array}{l}\text { Kania and Laskai debunk common misconceptions about } \\
\text { Chinese military-civil fusion, including its novelty, its } \\
\text { strategic significance, and its scope. They warn that } \\
\text { these false notions may drive decoupling policies that } \\
\text { would be "deeply damaging to American } \\
\text { competitiveness." }\end{array}$ \\
\hline $\begin{array}{l}\text { Rasser and } \\
\text { Lamberth } 2021\end{array}$ & $\begin{array}{l}\text { Rasser and Lamberth use historical examples to explain } \\
\text { lessons for U.S. science and technology policy. They } \\
\text { advocate for augmenting multilateral cooperation, raising } \\
\text { research and development investments, investing in } \\
\text { human capital and digital infrastructure, revising visa } \\
\text { policies, and defending against foreign technological } \\
\text { acquisition. }\end{array}$ \\
\hline Wagner 2021 & $\begin{array}{l}\text { Wagner cautions against restricting collaboration with } \\
\text { Chinese scientists and shunning Chinese students from } \\
\text { the United States, writing that "Closing doors inhibits the } \\
\text { very trait that makes the U.S. innovation system the envy } \\
\text { of the world." }\end{array}$ \\
\hline Mulvenon 2021 & $\begin{array}{l}\text { Mulvenon summarizes the current U.S.-China } \\
\text { technological standoff and offers policy suggestions, } \\
\text { including prioritizing export controls, reforming CFIUS, } \\
\text { and promulgating data standards. }\end{array}$ \\
\hline $\begin{array}{l}\text { Eurasia Group } \\
2021\end{array}$ & $\begin{array}{l}\text { This report reviews Chinese autonomous vehicle policies, } \\
\text { including investment and standards-development, but } \\
\text { underscores the challenges of talent retention, U.S. } \\
\text { countermoves, and semiconductor shortages. }\end{array}$ \\
\hline $\begin{array}{l}\text { Kastner and } \\
\text { Pearson } 2021\end{array}$ & $\begin{array}{l}\text { Kastner and Pearson review the literature on Chinese } \\
\text { economic influence, pointing out potential analytical and } \\
\text { empirical gaps and encouraging further study. }\end{array}$ \\
\hline
\end{tabular}




\begin{tabular}{|l|l|}
\hline $\begin{array}{l}\text { Center for } \\
\begin{array}{l}\text { Policy Analysis } \\
2021\end{array}\end{array}$ & $\begin{array}{l}\text { This discussion, featuring experts such as Edward Lucas } \\
\text { and Bryce Barros, covers concerns over Chinese } \\
\text { investments in European countries from Spain to } \\
\text { Romania. }\end{array}$ \\
\hline $\begin{array}{l}\text { U.S. } \\
\text { Department of } \\
\text { Justice 2021 }\end{array}$ & $\begin{array}{l}\text { A compendium of prosecutions with a China nexus, } \\
\text { including military-industrial espionage, economic } \\
\text { espionage, the Thousand Talents Program, cyberattacks, } \\
\text { and more. }\end{array}$ \\
\hline
\end{tabular}


Bibliography

Theory of Strategic Economic Competition and Statecraft

Klaus Knorr, "The Limits of Economic and Military Power," Daedalus 104, no. 4 (Fall 1975): 229-243, https://www.jstor.org/stable/20024372.

Cornelia Navari, "The Great Illusion Revisited: The International Theory of Norman Angell," Review of International Studies 15, no. 4 (October 1989): 341-358, https://doi.org/10.1017/S0260210500112756.

Tor Egil Førland, “'Economic Warfare' and 'Strategic Goods': A Conceptual Framework for Analyzing COCOM," Journal of Peace Research 28, no. 2 (May 1991): 191-204, https://doi.org/10.1177/0022343391028002005.

Tor Egil Førland, "The History of Economic Warfare: International Law, Effectiveness, Strategies," Journal of Peace Research 30, no. 2 (May 1993): 151-162, https://doi.org/10.1177/0022343393030002003.

Vincent Cable, "What Is International Economic Security?" International Affairs 71, no. 2 (April 1995): 305-324, https://doi.org/10.2307/2623436.

Katherine Barbieri, "Economic Interdependence: A Path to Peace or a Source of Interstate Conflict?," Journal of Peace Research 33, no. 1 (February 1996): 29-49, https://doi.org/10.1177/0022343396033001003.

T. Clifton Morgan and Valerie L. Schwebach, "Fools Suffer Gladly: The Use of Economic Sanctions in International Crises," International Studies Quarterly 41, no. 1 (March 1997): 27 50, https://doi.org/10.1111/0020-8833.00032.

Susan M. McMillan, "Interdependence and Conflict," Mershon International Studies Review 41, no. 1 (May 1997): 33-58, https://doi.org/10.2307/222802.

Robert A. Pape, "Why Economic Sanctions Do Not Work," International Security 22, no. 2 (Fall 1997): 90-136, https://doi.org/10.2307/2539368. 
Michael Mastanduno, "Economics and Security in Statecraft and Scholarship," International Organization 52, no. 4 (Autumn 1998): 825-854, https://doi.org/10.1162/002081898550761.

Katherine Barbieri and Jack S. Levy, "Sleeping with the Enemy: The Impact of War on Trade," Journal of Peace Research 36, no. 4 (July 1999): 463-479, https://doi.org/10.1177/0022343399036004005.

Peter Liberman, "The Offense-Defense Balance, Interdependence, and War," Security Studies 9, no. 1-2 (Autumn 1999/Winter 2000): 59-91, https://doi.org/10.1080/09636419908429395.

Rawi Abdelal and Jonathan Kirshner, "Strategy, Economic Relations, and the Definition of National Interests," Security Studies 9, no. 1-2 (Autumn 1999/Winter 2000): 119-156, https://doi.org/10.1080/09636419908429397.

Jean-Marc F. Blanchard and Norrin M. Ripsman, "Asking the Right Question: When Do Economic Sanctions Work Best?" Security Studies 9, no. 1-2 (Autumn 1999/Winter 2000): 219-253, https://doi.org/10.1080/09636419908429400.

Michael Mastanduno, "Economic Statecraft, Interdependence, and National Security: Agendas for Research," Security Studies 9, no. 1-2 (Autumn 1999/Winter 2000): 288-316, https://doi.org/10.1080/09636419908429402.

Stephen G. Brooks, "The Globalization of Production and the Changing Benefits of Conquest," Journal of Conflict Resolution 43, no. 5 (October 1999): 646-670, https://doi.org/10.1177/0022002799043005006.

Sean M. Bolks and Dina Al-Sowayel, "How Long Do Economic Sanctions Last? Examining the Sanctioning Process through Duration," Political Research Quarterly 53, no. 2 (June 2000): 241-265, https://doi.org/10.2307/449280.

Risa A. Brooks, "Sanctions and Regime Type: What Works, and When?," Security Studies 11, no. 4 (Summer 2002): 1-50, https://doi.org/10.1080/714005349. 
Fiona McGillivray and Allan C. Stam, "Political Institutions, Coercive Diplomacy, and the Duration of Economic Sanctions," Journal of Conflict Resolution 48, no. 2 (April 2004): 154172, https://doi.org/10.1177/0022002703262858.

Susan Hannah Allen, "The Determinants of Economic Sanctions Success and Failure," International Interactions 31, no. 2 (March 2005): 117-138, https://doi.org/10.1080/03050620590950097.

Gary Clyde Hufbauer, Jeffrey J. Schott, Kimberly Elliott, and Barbara Oegg, Economic Sanctions Reconsidered, 3rd ed. (Washington, DC: Peterson Institute for International Economics, 2007).

Håvard Hegre, John R Oneal, and Bruce Russett, “Trade Does Promote Peace: New Simultaneous Estimates of the Reciprocal Effects of Trade and Conflict," Journal of Peace Research 47, no. 6 (November 2010): 763-774, https://doi.org/10.1177/0022343310385995.

Sheila R. Ronis, ed., Economic Security: Neglected Dimension of National Security? (Washington, DC: National Defense University Press, 2011), https://ndupress.ndu.edu/Portals/68/Documents/Books/econ omic-security.pdf.

Erik Gartzke and Yonatan Lupu, "Trading on Preconceptions: Why World War I Was Not a Failure of Economic Interdependence," International Security 36, no. 4 (Spring 2012): 115-150, https://doi.org/10.1162/ISEC_a_00078.

Taehee Whang and Hannah June Kim, "International Signaling and Economic Sanctions," International Interactions 41, no. 3 (July/August 2015): 427-452, https://doi.org/10.1080/03050629.2015.1024242.

Jack Snyder, "Trade Expectations and Great Power Conflict-A Review Essay," International Security 40, no. 3 (Winter 2015/2016): 179-196, https://doi.org/10.1162/ISEC_r_00229. 
Robert D. Blackwill and Jennifer M. Harris, "The Lost Art of Economic Statecraft: Restoring an American Tradition," Foreign Affairs 95, no. 2 (March/April 2016): 99-110, https://www.jstor.org/stable/43948183.

Joanne Gowa and Raymond Hicks, "Commerce and Conflict: New Data about the Great War," British Journal of Political Science 47, no. 3 (July 2017): 653-674, https://doi.org/10.1017/S0007123415000289.

Daniel McCormack and Henry Pascoe, "Sanctions and Preventive War," Journal of Conflict Resolution 61, no. 8 (September 2017): 1711-1739, https://doi.org/10.1177/0022002715620471.

Anthea Roberts, Henrique Choer Moraes, and Victor Ferguson, "Geoeconomics: The Variable Relationship between Economics and Security," Lawfare, November 27, 2018, https://www.lawfareblog.com/geoeconomics-variablerelationship-between-economics-and-security.

Daniel W. Drezner, Henry Farrell, and Abraham L. Newman, eds., The Uses and Abuses of Weaponized Interdependence (Washington, D.C.: Brookings Institution Press, 2021). 
Export Controls and Technology Transfer during the Cold War

CIA Directorate of Intelligence, COCOM Countries' Sales of

Technology to the USSR and Eastern Europe (Langley, VA:

Central Intelligence Agency, September 1970), https://www.cia.gov/readingroom/document/ciardp85t00875r001600030121-4.

Defense Science Board Task Force on Export of U.S. Technology, An Analysis of Export Control of U.S. Technology - A DOD Perspective (Washington, DC: U.S. Department of Defense, February 4, 1976),

https://apps.dtic.mil/dtic/tr/fulltext/u2/a022029.pdf.

Office of Technology Assessment, Technology and East-West Trade (Washington, DC: U.S. Government Printing Office, November 1979), https://www.princeton.edu/ ota/disk3/1979/7918/7918.PD F.

Angela Stent Yergin, East-West Technology Transfer: European Perspectives (Beverly Hills, CA: SAGE Publications, 1980).

J. Fred Bucy, "Technology Transfer and East-West Trade: A Reappraisal," International Security 5, no. 3 (Winter 1980/1981): 132-151, https://doi.org/10.2307/2538423.

Rodney P. G. Bricker, U.S. Technology Transfer to the Soviet Union: A Dilemma (Montgomery, AL: Air War College, April 1981), https://apps.dtic.mil/dtic/tr/fulltext/u2/a107313.pdf.

Thane Gustafson, Selling the Russians the Rope? Soviet Technology Policy and U.S. Export Controls (Santa Monica, CA: RAND Corporation, 1981), https://www.rand.org/content/dam/rand/pubs/reports/2008/ R2649.pdf.

Director of Central Intelligence, Dependence of Soviet Military Power on Economic Relations with the West (Langley, VA: 
Central Intelligence Agency, November 17, 1981), https://www.cia.gov/readingroom/document/0000681971.

Central Intelligence Agency, Background Notes: Technology

Transfer Losses and Some Actions to Stop Them (Langley, VA: Central Intelligence Agency, 1982), https://www.cia.gov/readingroom/document/ciardp84b00049r001102690018-9.

Director of Central Intelligence, Allied Attitudes toward Export Controls (Langley, VA: Central Intelligence Agency, January 5, 1982), https://www.cia.gov/readingroom/document/ciardp08s01350r000401070002-4.

U.S. Congress, Senate, Committee on Governmental Affairs, Hearings, Transfer of United States High Technology to the Soviet Union and Soviet Bloc Nations, 97th Congress, 2nd Session, May 4, 5, 6, 11, and 12, 1982 (Washington, DC: U.S. Government Printing Office, 1982), https://babel.hathitrust.org/cgi/pt?id=mdp.3901500870346 7.

Ellen L. Frost and Angela E. Stent, "NATO's Troubles with EastWest Trade," International Security 8, no. 1 (Summer 1983): 179-200, https://doi.org/10.2307/2538491.

William A. Root, "Trade Controls That Work," Foreign Policy no. 56 (Autumn 1984): 61-80, https://doi.org/10.2307/1148474.

Steven D. Overly, "Regulation of Critical Technologies under the Export Administration Act of 1979 and the Proposed Export Administration Amendments of 1983: American Business Versus National Security," North Carolina Journal of International Law and Commercial Regulation 10, no. 2 (Spring 1985): 423-462, https://scholarship.law.unc.edu/cgi/viewcontent.cgi?article=1 266\&context=ncilj.

Beverly Crawford and Stefanie Lenway, "Decision Modes and International Regime Change: Western Collaboration on 
East-West Trade," World Politics 37, no. 3 (April 1985):

375-402, https://doi.org/10.2307/2010248.

CIA Directorate of Intelligence, Truck Production at the Soviet

Kama River Plant-Western Technology in Action (Langley, VA: Central Intelligence Agency, August 1985), https://www.cia.gov/readingroom/document/ciardp86t00591r000300400003-5.

Central Intelligence Agency, Soviet Acquisition of Militarily Significant Western Technology: An Update (Langley, VA: Central Intelligence Agency, September 1985), https://www.cia.gov/readingroom/document/ciardp96b01172r000700060001-8.

Yoko Yasuhara, "Japan, Communist China, and Export Controls in Asia, 1948-52," Diplomatic History 10, no. 1 (January 1986): 75-89, https://doi.org/10.1111/j.14677709.1986.tb00451.x.

Homer O. Blair, "Export Controls on Nonmilitary Goods and Technology: Are We Penalizing the Soviets or Ourselves?," Texas International Law Journal 21, no. 2 (Spring 1986): 363-372, https://heinonline.org/HOL/P?h=hein.journals/tilj21\&i=373.

Margaret J. Lam, "Restrictions on Technology Transfer among Academic Researchers: Will Recent Changes in the Export Control System Make a Difference?," Journal of College and University Law 13, no. 3 (Winter 1986): 311-334, https://heinonline.org/HOL/P?h=hein.journals/jcolunly13\&i=3 $\underline{55}$.

Alan P. Dobson, "The Kennedy Administration and Economic Warfare against Communism," International Affairs 64, no. 4 (Autumn 1988): 599-616, https://doi.org/10.2307/2626045.

Matthew W. Sawchak, “The Department of Defense's Role in FreeWorld Export Licensing under the Export Administration Act," Duke Law Journal 1988, no. 4 (September 1988): 785- 
817,

https://scholarship.law.duke.edu/cgi/viewcontent.cgi?article= 3048\&context $=$ dlj.

Stephen D. Kelly, "Curbing Illegal Transfers of Foreign-Developed Critical High Technology from CoCom Nations to the Soviet Union: An Analysis of the Toshiba-Kongsberg Incident," Boston College International and Comparative Law Review 12, no. 1 (Winter 1989): 181-223, https://lawdigitalcommons.bc.edu/cgi/viewcontent.cgi?article $\equiv$ 1379\&context=iclr.

Wende A. Wrubel, "The Toshiba-Kongsberg Incident:

Shortcomings of Cocom, and Recommendations for Increased Effectiveness of Export Controls to the East Bloc," American University International Law Review 4, no. 1 (Winter 1989): 241-273, https://digitalcommons.wcl.american.edu/cgi/viewcontent.cg i?article $=1604 \&$ context=auilr.

U.S. Congress, House of Representatives Committee on Science, Space, and Technology, Hearing, International Technology Transfer: Who Is Minding the Store?, 101st Congress, 1st Session, July 19, 1989 (Washington, DC: U.S. Government Printing Office, 1990), https://babel.hathitrust.org/cgi/pt?id=pst.000015611154.

Seymour E. Goodman, Marjory S. Blumenthal, and Gary L. Geipel, "Export Control Reconsidered," Issues in Science and Technology 6, no. 2 (Winter 1989/1990): 58-62, https://www.jstor.org/stable/43309449.

Baker Spring, "Controls Still Needed on High Technology Exports to the U.S.S.R." (Heritage Foundation, August 2, 1990), https://www.heritage.org/trade/report/controls-still-neededhigh-technology-exports-the-ussr.

Michael Mastanduno, Economic Containment: CoCom and the Politics of East-West Trade (Ithaca, NY: Cornell University Press, 1992). 
Beverly Crawford, Economic Vulnerability in International

Relations: The Case of East-West Trade, Investment, and Finance (New York: Columbia University Press, 1993).

John H. Henshaw, "The Origins of COCOM: Lessons for Contemporary Proliferation Control Regimes" (The Stimson Center, May 1993), https://www.stimson.org/wpcontent/files/file-attachments/Report7_1.pdf.

Kirsten Lundberg, "CIA and the Fall of the Soviet Empire: The Politics of 'Getting It Right"' (Harvard University, 1994), https://www.cia.gov/readingroom/document/0005302423.

Gus W. Weiss, “The Farewell Dossier," Studies in Intelligence 39, no. 5 (1996): 121-126, https://www.cia.gov/static/887689795bd91ed08ca926a2f6 278ee4/The-Farewell-Dossier.pdf.

Christopher Andrew and Vasili Mitrokhin, The Sword and the Shield: The Mitrokhin Archive and the Secret History of the KGB (New York: Basic Books, 1999).

Allen Weinstein and Alexander Vassiliev, The Haunted Wood: Soviet Espionage in America - The Stalin Era (New York: Random House, 1999).

Katherine A. S. Sibley, "Soviet Industrial Espionage against American Military Technology and the US Response, 19301945," Intelligence and National Security 14, no. 2 (Summer 1999): 94-123, https://doi.org/10.1080/02684529908432541.

lan Jackson, “'The Limits of International Leadership': The Eisenhower Administration, East-West Trade and the Cold War, 1953-54," Diplomacy \& Statecraft 11, no. 3

(November 2000): 113-138, https://doi.org/10.1080/09592290008406173.

Kristie Macrakis, "Does Effective Espionage Lead to Success in Science and Technology? Lessons from the East German Ministry for State Security," Intelligence and National 
Security 19, no. 1 (Spring 2004): 52-77, https://doi.org/10.1080/0268452042000222920.

Jeffrey A. Engel, "Of Fat and Thin Communists: Diplomacy and Philosophy in Western Economic Warfare Strategies toward China (and Tyrants, Broadly)," Diplomatic History 29, no. 3 (June 2005): 445-474, https://doi.org/10.1111/j.14677709.2005.00499.x.

Alan P. Dobson, "The Reagan Administration, Economic Warfare, and Starting to Close Down the Cold War," Diplomatic History 29, no. 3 (June 2005): 531-556, https://doi.org/10.1111/j.1467-7709.2005.00502.x.

Kristie Macrakis, Seduced by Secrets: Inside the Stasi's Spy-Tech World (New York: Cambridge University Press, 2008).

Soo Chun Lu, “'Trade with the Devil': Rubber, Cold War Embargo, and US-Indonesian Relations, 1951-1956," Diplomacy \& Statecraft 19, no. 1 (March 2008): 42-68, https://doi.org/10.1080/09592290801913700.

Alan P. Dobson, "From Instrumental to Expressive: The Changing Goals of the U.S. Cold War Strategic Embargo," Journal of Cold War Studies 12, no. 1 (Winter 2010): 98-119, https://doi.org/10.1162/jcws.2010.12.1.98.

Austin Long, "Rubles, Dollars, and Power: U.S. Intelligence on the Soviet Economy and Long-Term Competition," Texas National Security Review 1, no. 4 (August 2018), http://doi.org/10.15781/T2NV99X6Q.

Niklas Jensen-Eriksen, "The Northern Front in the Technological Cold War: Finland and East-West Trade in the 1970s and 1980s," Journal of Cold War Studies 21, no. 4 (Fall 2019): 150-174, https://doi.org/10.1162/jcws_a_00909.

Alex French, "The Secret History of a Cold War Mastermind," WIRED, March 11, 2020, https://www.wired.com/story/thesecret-history-of-a-cold-war-mastermind. 
Susan Colbourn, “An Interpreter or Two: Defusing NATO's Siberian Pipeline Dispute, 1981-1982," Journal of Transatlantic Studies 18, no. 2 (June 2020): 131-151, https://doi.org/10.1057/s42738-020-00046-x. 
Strategic Economic Competition and Export Controls after the Cold War

William H. Webster, Remarks by William H. Webster, Director of Central Intelligence, to the Los Angeles World Affairs Council, Los Angeles, California, September 19, 1989 (Langley, VA: Central Intelligence Agency, September 19, 1989), https://www.cia.gov/readingroom/document/ciardp99-01448r000401640021-1.

Theodore H. Moran, "The Globalization of America's Defense Industries: Managing the Threat of Foreign Dependence," International Security 15, no. 1 (Summer 1990): 57-99, https://doi.org/10.2307/2538982.

Kay Oliver, "Analyzing Economic Espionage," Studies in Intelligence 36, no. 1 (Spring 1992): 23-27, https://www.cia.gov/readingroom/docs/DOC_0000622857. pdf.

Lynn E. Davis, "Export Controls and Non-proliferation Regimes in the Post-Cold War World," U.S. Department of State Dispatch 5, no. 11 (March 14, 1994): 149-152, https://hdl.handle.net/2027/umn.31951d02928576f.

Charles L. Evans, "U.S. Export Control of Encryption Software: Efforts to Protect National Security Threaten the U.S. Software Industry's Ability to Compete in Foreign Markets," North Carolina Journal of International Law and Commercial Regulation 19, no. 3 (Summer 1994): 469-490, https://scholarship.law.unc.edu/cgi/viewcontent.cgi?article=1 536\&context=ncilj.

Rochelle M. Tarlowe, "Deregulating Dual-Use Exports to Russia: Is U.S. National Security at Risk?," Fordham International Law Journal 18, no. 3 (March 1995): 959-1004, https://ir.lawnet.fordham.edu/cgi/viewcontent.cgi?referer=\&h ttpsredir=1\&article $=1426 \&$ context=ilj.

Irving Lachow, "The GPS Dilemma: Balancing Military Risks and Economic Benefits," International Security 20, no. 1 
(Summer 1995): 126-148,

https://doi.org/10.2307/2539220.

John Arquilla, "Between a Rock and a Hard-Drive: Export Controls on Supercomputers," The Nonproliferation Review 3, no. 2 (Winter 1996): 55-61, https://doi.org/10.1080/10736709608436623.

Richard T. Cupitt and Suzette R. Grillot, "COCOM Is Dead, Long Live COCOM: Persistence and Change in Multilateral Security Institutions," British Journal of Political Science 27, no. 3 (July 1997): 361-389, https://doi.org/10.1017/S0007123497000185.

James Bonomo et al., Monitoring and Controlling the International Transfer of Technology (Santa Monica, CA: RAND Corporation, 1998), https://www.rand.org/pubs/monograph_reports/MR979.htm !

Robert Johnston, "U.S. Export Control Policy in the High Performance Computer Sector," The Nonproliferation Review 5, no. 2 (Winter 1998): 44-59, https://doi.org/10.1080/10736709808436706.

Cassady B. Craft and Suzette R. Grillot, "Transparency and the Effectiveness of Multilateral Nonproliferation Export Control Regimes: Can Wassenaar Work?," Southeastern Political Review 27, no. 2 (June 1999): 281-302, https://doi.org/10.1111/j.1747-1346.1999.tb00536.x.

Michael Lipson, "The Reincarnation of CoCom: Explaining PostCold War Export Controls," The Nonproliferation Review 6, no. 2 (Winter 1999): 33-51, https://doi.org/10.1080/10736709908436748.

Candace Howes and Ajit Singh, eds., Competitiveness Matters: Industry and Economic Performance in the U.S. (Ann Arbor, MI: University of Michigan Press, 2000). 
Jeanne J. Grimmett, “Encryption Export Controls” (Congressional Research Service, January 11, 2001), https://fas.org/irp/crs/RL30273.pdf.

U.S. Congress, Senate Committee on Governmental Affairs, Hearing, High Performance Computer Export Controls, 107th Congress, 1st Session, March 15, 2001 (Washington, DC: U.S. Government Printing Office, 2001), https://www.govinfo.gov/content/pkg/CHRG107shrg72196/pdf/CHRG-107shrg72196.pdf.

Shirley A. Kan, "China: Possible Missile Technology Transfers from U.S. Satellite Export Policy - Actions and Chronology" (Congressional Research Service, September 5, 2001), https://fas.org/sgp/crs/nuke/98-485.pdf.

Glenn J. McLoughlin and lan F. Fergusson, "High Performance Computers and Export Control Policy: Issues for Congress" (Congressional Research Service, May 5, 2005), https://fas.org/sgp/crs/natsec/RL31175.pdf.

Richard Van Atta et al., "Export Controls and the U.S. Defense Industrial Base" (Institute for Defense Analyses, January 2007), https://apps.dtic.mil/dtic/tr/fulltext/u2/a465592.pdf.

Titus Galama and James Hosek, U.S. Competitiveness in Science and Technology (Santa Monica, CA: RAND Corporation, 2008), https://apps.dtic.mil/sti/pdfs/ADA482598.pdf.

"Briefing of the Working Group on the Health of the U.S. Space Industrial Base and the Impact of Export Controls" (Center for Strategic and International Studies, February 19, 2008), https://www.csis.org/analysis/health-us-space-industrialbase-and-impact-export-controls.

Pierre Chao, "Toward a U.S. Export Control and Technology Transfer System for the 21st Century" (Center for Strategic and International Studies, May 15, 2008), https://www.csis.org/analysis/toward-us-export-controland-technology-transfer-system-21st-century. 
John F. Sargent, "Nanotechnology and U.S. Competitiveness: Issues and Options" (Congressional Research Service, May 15, 2008), https://apps.dtic.mil/sti/pdfs/ADA483318.pdf.

U.S. Congress, House of Representatives Committee on Foreign Affairs, Hearing, The Impact of U.S. Export Controls on National Security, Science and Technological Leadership, 111th Congress, 2nd Session, January 15, 2010 (Washington, DC: U.S. Government Printing Office, 2010), https://fas.org/irp/congress/2010_hr/export.pdf.

Robin L. Kuntz, "How Not to Catch a Thief: Why the Economic Espionage Act Fails to Protect American Trade Secrets," Berkeley Technology Law Journal 28 (2013): 901-933, http://dx.doi.org/10.15779/Z38112K.

Rochelle Cooper Dreyfuss and Orly Lobel, "Economic Espionage as Reality or Rhetoric: Equating Trade Secrecy with National Security," Lewis \& Clark Law Review 20, no. 2 (2016): 419475, https://law.Iclark.edu/live/files/22071Icb202art3dreyfuss-lobelpdf. 
Economic and Technological Competition: U.S.-Japan

Sadako Ogata, "Some Japanese Views on United States-Japan Relations in the 1980s," Asian Survey 20, no. 7 (July 1980): 694-706, https://doi.org/10.2307/2643923.

Victor Basiuk, The Threat of Foreign Competition to U.S. High Technology Industries: National Security Considerations (Washington, DC: U.S. Department of Commerce, April 1982), https://www.cia.gov/readingroom/document/ciardp85t00153r000300070005-7. ${ }^{1}$

C. Fred Bergsten, "What to Do about the U.S.-Japan Economic Conflict," Foreign Affairs 60, no. 5 (Summer 1982): 10591075, https://doi.org/10.2307/20041275.

Saburo Okita, "Japanese-American Economic Troubles: Lowering the Temperature," International Security 7, no. 2 (Fall 1982): 198-203, https://doi.org/10.2307/2538439.

Cabinet Council on Commerce and Trade, An Assessment of U.S. Competitiveness in High Technology Industries (Washington, DC: U.S. Department of Commerce, October 1982), https://www.cia.gov/readingroom/document/ciardp84b00049r001700240013-9.

Office of Technology Assessment, International Competitiveness in Electronics (Washington, DC: U.S. Government Printing Office, November 1983), https://ota.fas.org/reports/8314.pdf.

Richard J. Caccamise et al., U.S. Dependency on Foreign Sources for Components: The Case of Semiconductors (Washington, DC: National Defense University, March 1983), https://apps.dtic.mil/sti/pdfs/ADA138104.pdf.

John Zysman and Stephen S. Cohen, "Double or Nothing: Open Trade and Competitive Industry," Foreign Affairs 61, no. 5 (Summer 1983): 1113-1139, https://doi.org/10.2307/20041639. 
Victoria L. Hatter, U.S. High Technology Trade and

Competitiveness (Washington, DC: U.S. Department of Commerce, February 1985), https://hdl.handle.net/2027/mdp.39015019781940.

Chalmers Johnson, "How to Think about Economic Competition from Japan," Journal of Japanese Studies 13, no. 2 (Summer 1987): 415-427, https://doi.org/10.2307/132476.

Charles H. Ferguson, “America's High-Tech Decline," Foreign Policy no. 74 (Spring 1989): 123-144, https://doi.org/10.2307/1148856.

James Fallows, "Containing Japan," The Atlantic, May 1989, https://www.theatlantic.com/magazine/archive/1989/05/con taining-japan/376337.

Joint Economic Committee, Japan's Economic Challenge, 101st Congress, 2nd Session, October 1990 (Washington, DC: U.S. Government Printing Office, 1990), https://www.jec.senate.gov/reports/101st\%20Congress/Jap an's\%20Economic\%20Challenge\%20(1525).pdf.

Office of Technology Assessment, Competing Economies: America, Europe, and the Pacific Rim (Washington, DC: U.S. Government Printing Office, October 1991), https://ota.fas.org/reports/9112.pdf.

John Zysman, "US Power, Trade and Technology," International Affairs 67, no. 1 (January 1991): 81-106, https://doi.org/10.2307/2621220.

Michael Mastanduno, "Do Relative Gains Matter? America's Response to Japanese Industrial Policy," International Security 16, no. 1 (Summer 1991): 73-113, https://doi.org/10.2307/2539052.

Joseph S. Nye, Jr., "Coping with Japan," Foreign Policy no. 89 (Winter 1992/1993): 96-115, https://doi.org/10.2307/1149076. 
Laura D'Andrea Tyson, Who's Bashing Whom? Trade Conflict in High Technology Industries (Washington, DC: Institute for International Economics, 1993).

Michael Mastanduno, "Models, Markets, and Power: Political Economy and the Asia-Pacific, 1989-1999," Review of International Studies 26, no. 4 (October 2000): 493-507, https://doi.org/10.1017/S0260210500004939.

Narrelle Morris, Japan-Bashing: Anti-Japanism since the 1980s (New York: Routledge, 2011).

Steve Lohr, "Maybe Japan Was Just a Warm-Up," The New York Times, January 21, 2011, https://www.nytimes.com/2011/01/23/business/23japan.ht $\underline{\mathrm{ml}}$.

Jennifer M. Miller, “Adam Smith's Arthritis: Japan and the Fear of American Decline," Ronald Reagan and the Transformation of the 1980s, Clements Center for National Security (January 18-22, 2017), University of Texas-Austin, https://www.cspan.org/video/?c4798644/user-clip-adam-smiths-arthritis.

Rosemary Foot, "Power Transitions and Great Power Management: Three Decades of China-Japan-US Relations," The Pacific Review 30, no. 6 (March 2017): 829-842, https://doi.org/10.1080/09512748.2017.1303535.

Peter Landers, "The Old U.S. Trade War with Japan Looms over Today's Dispute with China," The Wall Street Journal, December 13, 2018, https://www.wsj.com/articles/the-oldu-s-trade-war-with-japan-looms-over-todays-disputewith-china-11544717163.

Yeling Tan, "Will U.S. Trade Pressure Actually Change China's Industrial Policy?," The Washington Post, December 20, 2018, https://www.washingtonpost.com/news/monkeycage/wp/2018/12/20/will-u-s-trade-pressure-actuallychange-chinas-industrial-policy. 
Shujiro Urata, "US-Japan Trade Frictions: The Past, the Present, and Implications for the US-China Trade War," Asian Economic Policy Review 15, no. 1 (January 2020): 141-159, https://doi.org/10.1111/aepr.12279. 
Strategic, Economic, and Technological Competition:

U.S.-China

CIA Directorate of Intelligence, China: Limitations on Technology Absorption (Langley, VA: Central Intelligence Agency, December 1983), https://www.cia.gov/readingroom/document/ciardp84s00928r000200080004-0.

Elizabeth M. Nimmo, “United States Policy Regarding Technology Transfer to the People's Republic of China," Northwestern Journal of International Law and Business 6, no. 1 (Spring 1984): 249-274, https://scholarlycommons.law.northwestern.edu/cgi/viewcon tent.cgi?article $=1171 \&$ context $=$ njilb.

Jong-Tsong Chiang, "Dilemmas of U.S. Export Control of Technology Transfer to China" (Massachusetts Institute of Technology, September 1987), https://dspace.mit.edu/bitstream/handle/1721.1/47206/dile mmasofusexpo00chia.pdf.

Jing-Dong Yuan, "United States Technology Transfer Policy toward China: Post-Cold War Objectives and Strategies," International Journal 51, no. 2 (Spring 1996): 314-338, https://doi.org/10.1177/002070209605100206.

U.S. Congress, House of Representatives Select Committee on U.S. National Security and Military/Commercial Concerns with the People's Republic of China, Report, U.S. National Security and Military/Commercial Concerns with the People's Republic of China, 105th Congress, 2nd Session, May 25, 1999 (Washington, DC: U.S. Government Printing Office, 1999), https://www.govinfo.gov/content/pkg/GPOCRPT-105hrpt851/pdf/GPO-CRPT-105hrpt851.pdf.

Paul A. Papayoanou and Scott L. Kastner, "Sleeping with the (Potential) Enemy: Assessing the U.S. Policy of Engagement with China," Security Studies 9, no. 1-2 (Autumn 
1999/Winter 2000): 157-187,

https://doi.org/10.1080/09636419908429398.

Evan A. Feigenbaum, "Patterns of Chinese Policies on Technology Transfer," Journal of American-East Asian Relations 9, no. 12 (Spring/Summer 2000): 107-128, https://doi.org/10.1163/187656100793645949.

Adam Segal, "Practical Engagement: Drawing a Fine Line for U.S.China Trade," The Washington Quarterly 27, no. 3 (Summer 2004): 157-173, https://doi.org/10.1162/016366004323090313.

Richard P. Suttmeier, "Assessing China's Technology Potential," Georgetown Journal of International Affairs 5, no. 2 (Summer/Fall 2004): 97-105, https://www.jstor.org/stable/43134293.

George J. Gilboy, "The Myth behind China's Miracle," Foreign Affairs 83, no. 4 (July/August 2004): 33-48, https://doi.org/10.2307/20034045.

Daniel W. Drezner, "Bad Debts: Assessing China's Financial Influence in Great Power Politics," International Security 34, no. 2 (Fall 2009): 7-45, https://doi.org/10.1162/isec.2009.34.2.7.

Aaron L. Friedberg, "Implications of the Financial Crisis for the USChina Rivalry," Survival 52, no. 4 (August/September 2010): 31-54, https://doi.org/10.1080/00396338.2010.506817.

Michael Beckley, “China's Century? Why America's Edge Will Endure," International Security 36, no. 3 (Winter 2011/2012): 41-78, https://doi.org/10.1162/ISEC_a_00066.

Derek Scissors and Arvind Subramanian, "The Great China Debate: Will Beijing Rule the World?," Foreign Affairs 91, no. 1 (January/February 2012): 173-177, https://www.jstor.org/stable/23217160. 
John Van Reenen and Linda Yueh, "Why Has China Grown So Fast? The Role of International Technology Transfer" (London School of Economics, February 2012), https://cep.Ise.ac.uk/pubs/download/dp1121.pdf.

William C. Hannas, James Mulvenon, and Anna B. Puglisi, Chinese Industrial Espionage: Technology Acquisition and Military Modernization (New York: Routledge, 2013).

Oliver Bräuner, "Beyond the Arms Embargo: EU Transfers of Defense and Dual-Use Technologies to China," Journal of East Asian Studies 13, no. 3 (December 2013): 457-482, https://doi.org/10.1017/S1598240800008304.

Tomoo Marukawa, "Japan's High-Technology Trade with China and Its Export Control," Journal of East Asian Studies 13, no. 3 (December 2013): 483-501, https://doi.org/10.1017/S1598240800008316.

Yoram Evron, "Between Beijing and Washington: Israel's Technology Transfers to China," Journal of East Asian Studies 13, no. 3 (December 2013): 503-528, https://doi.org/10.1017/S1598240800008328.

Jen Weedon, "Hearing on Commercial Cyber Espionage and Barriers to Digital Trade in China," testimony before the U.S.-China Economic and Security Review Commission, June 15, 2015, https://www.uscc.gov/sites/default/files/Weedon\%20Testim ony.pdf.

Stephen G. Brooks and William Wohlforth, "The Rise and Fall of the Great Powers in the Twenty-First Century: China's Rise and the Fate of America's Global Position," International Security 40, no. 3 (Winter 2015/2016): 7-53, https://doi.org/10.1162/ISEC_a_00225.

Peter Harrell, Elizabeth Rosenberg, and Edoardo Saravalle, "China's Use of Coercive Economic Measures" (Center for a New American Security, June 2018), 
https://s3.amazonaws.com/files.cnas.org/documents/China Use_FINAL-1.pdf.

Elsa B. Kania, "China's Threat to American Government and Private Sector Research and Innovation Leadership," testimony before the House Permanent Select Committee on Intelligence, July 19, 2018, https://congress.gov/115/meeting/house/108561/witnesses/ HHRG-115-IG00-Wstate-KaniaE-20180719.pdf.

Anthea Roberts, Henrique Choer Moraes, and Victor Ferguson, "The Geoeconomic World Order," Lawfare, November 19, 2018, https://www.lawfareblog.com/geoeconomic-worldorder.

Andrea Gilli and Mauro Gilli, "Why China Has Not Caught up Yet: Military-Technological Superiority and the Limits of Imitation, Reverse Engineering, and Cyber Espionage," International Security 43, no. 3 (Winter 2018/2019): 141189, https://doi.org/10.1162/ISEC_a_00337.

Tai Ming Cheung, William Lucyshyn, and John Rigilano, “The Role of Technology Transfers in China's Defense Technological and Industrial Development and the Implications for the United States" (Naval Postgraduate School, February 5, 2019), https://dair.nps.edu/bitstream/123456789/2756/1/UCSDAM-19-028.pdf.

Hilary McGeachy, "US-China Technology Competition: Impacting a Rules-Based Order" (United States Studies Centre, May 2019), https://www.ussc.edu.au/analysis/us-chinatechnology-competition-impacting-a-rules-based-order.

Darren Lim and Victor Ferguson, "Huawei and the U.S.-China Supply Chain Wars: The Contradictions of a Decoupling Strategy," War on the Rocks, May 30, 2019, https://warontherocks.com/2019/05/huawei-and-the-u-schina-supply-chain-wars-the-contradictions-of-adecoupling-strategy. 
Helen Toner, “Technology, Trade, and Military-Civil Fusion: China's Pursuit of Artificial Intelligence, New Materials, and New Energy," testimony before the U.S.-China Economic and Security Review Commission, June 7, 2019, https://www.uscc.gov/sites/default/files/June\%207\%20Hear ing_Panel\%201_Helen\%20Toner_Written\%20Testimony\% 20on\%20China\%27s\%20Pursuit\%20of\%20Al.pdf.

James Andrew Lewis, "Emerging Technologies and Managing the Risk of Tech Transfer to China" (Center for Strategic and International Studies, September 2019), https://csiswebsite-prod.s3.amazonaws.com/s3fspublic/publication/190904_Lewis_ChinaTechTransfer_WEB _v2_1.pdf.

Charles W. Boustany, Jr. and Aaron L. Friedberg, "Partial Disengagement: A New U.S. Strategy for Economic Competition with China" (National Bureau of Asian Research, November 2019), https://www.nbr.org/wpcontent/uploads/pdfs/publications/sr82_china-task-forcereport-final.pdf.

Andrés Ortega, "The U.S.-China Race and the Fate of Transatlantic Relations: Part 1: Tech, Values, and Competition" (Center for Strategic and International Studies, January 2020), https://csis-website-prod.s3.amazonaws.com/s3fspublic/publication/200113_USChinaTranstlanticRelations.pd f.

Henry Farrell and Abraham L. Newman, "Chained to Globalization: Why It's Too Late to Decouple," Foreign Affairs, January/February 2020, https://www.foreignaffairs.com/articles/united-states/201912-10/chained-globalization.

Daniel W. Drezner, "How to Make America Less Productive," The Washington Post, June 10, 2020, https://www.washingtonpost.com/outlook/2020/06/10/how -make-america-less-productive. 
Scott Kennedy, "Washington's China Policy Has Lost Its Wei"

(Center for Strategic and International Studies, July 2020), https://csis-website-prod.s3.amazonaws.com/s3fspublic/publication/200727_Kennedy_USChinaPolicyLostBrief_v3.pdf.

Derek Scissors, "Partial Decoupling from China: A Brief Guide" (American Enterprise Institute, July 2020), https://www.aei.org/wp-content/uploads/2020/07/Partialdecoupling-from-China.pdf.

Gloria Xiong, "Beijing Increasingly Relies on Economic Coercion to Reach Its Diplomatic Goals," The Washington Post, July 23, 2020, https://www.washingtonpost.com/politics/2020/07/23/beijin g-increasingly-relies-economic-coercion-reach-itsdiplomatic-goals.

Elsa B. Kania and Lorand Laskai, "Myths and Realities of China's Military-Civil Fusion Strategy" (Center for a New American Security, January 2021), https://s3.us-east1.amazonaws.com/files.cnas.org/documents/Myths-andRealities-of-China\%E2\%80\%99s-Military-Civil-FusionStrategy_FINAL-min.pdf.

Martijn Rasser and Megan Lamberth, "Taking the Helm: A National Technology Strategy to Meet the China Challenge" (Center for a New American Security, January 2021), https://s3.useast-1.amazonaws.com/files.cnas.org/documents/Takingthe-Helm_FINAL-compressed.pdf.

Caroline Wagner, "Intense Scrutiny of Chinese-Born Researchers in the US Threatens Innovation," The Conversation, January 26, 2021, https://theconversation.com/intense-scrutiny-ofchinese-born-researchers-in-the-us-threatens-innovation153688.

James Mulvenon, "A World Divided: The Conflict with Chinese Techno-Nationalism Isn't Coming - It's Already Here," War on the Rocks, January 28, 2021, https://warontherocks.com/2021/01/a-world-divided-the- 
conflict-with-chinese-techno-nationalism-isnt-coming-itsalready-here.

"Chinese Autonomous Vehicle Industry Faces Geopolitical Headwinds" (Eurasia Group, March 2021), https://www.eurasiagroup.net/files/upload/chinese-autovehicle-industry-faces-geopolitical-headwinds.pdf.

Scott L. Kastner and Margaret M. Pearson, "Exploring the Parameters of China's Economic Influence," Studies in Comparative International Development 56, no. 1 (March 2021): 18-44, https://doi.org/10.1007/s12116-021-093189.

"Chinese Economic Influence: Too Good to be True?," Center for European Policy Analysis, March 11, 2021 , https://www.youtube.com/watch?v=nJGee1Qwi8Q.

U.S. Department of Justice, "Information about the Department of Justice's China Initiative and a Compilation of China-Related Prosecutions since 2018," last updated June 14, 2021, https://www.justice.gov/opa/information-about-departmentjustice-s-china-initiative-and-compilation-china-related. 


\section{Authors}

Adam Kline is a student research assistant at CSET, where Tim Hwang is a research fellow.

\section{Acknowledgments}

We would like to thank Catherine Aiken, Tessa Baker, Avonelle Davis, Melissa Deng, Shelton Fitch, Alex Friedland, Igor MikolicTorreira, Professor Abraham Newman, and Lynne Weil for their valuable feedback and assistance.

\section{(c) 9}

(c) 2021 by the Center for Security and Emerging Technology. This work is licensed under a Creative Commons Attribution-Non Commercial 4.0 International License.

To view a copy of this license, visit https://creativecommons.org/licenses/by-nc/4.0/. 


\section{Endnotes}

${ }^{1}$ Basiuk's authorship of the study is revealed in U.S. Congress, House of Representatives Committee on Merchant Marine and Fisheries, Hearings, Maritime Redevelopment, 98th Congress, 2nd Session, January 18, April 30, June 20, August 8, and November 9, 1984 (Washington, DC: U.S. Government Printing Office, 1985), 797, https://hdl.handle.net/2027/uc1.31210012865976. 